$\begin{array}{ll}\text { Research Square } & \begin{array}{l}\text { Preprints are preliminary reports that have not undergone peer review. } \\ \text { They should not be considered conclusive, used to inform clinical practice, } \\ \text { or referenced by the media as validated information. }\end{array}\end{array}$

\title{
Source Apportionment, Ecological And Human Health Risks of Toxic Metals In Road Dust of Densely Populated Capital And Connected Major Highway of Bangladesh
}

Md. Morshedul Haque ( $\square$ morshedulhaq@gmail.com)

Jahangirnagar University, Department of Environmental Sciences https://orcid.org/0000-0001-9799-6948

Sajin Sultana

Jahangirnagar University

Nahin Mostofa Niloy

Jahangirnagar University

Shamshad B. Quraishi

Bangladesh Atomic Energy Commission

Shafi M. Tareq

Jahangirnagar University

Research Article

Keywords: Toxic metals, Road dust, Positive matrix factorization, Ecological risk, Human health risk

Posted Date: September 8th, 2021

DOI: https://doi.org/10.21203/rs.3.rs-759865/v1

License: (c) (1) This work is licensed under a Creative Commons Attribution 4.0 International License. Read Full License

Version of Record: A version of this preprint was published at Environmental Science and Pollution Research on January 15th, 2022. See the published version at https://doi.org/10.1007/s11356-021-18458-3. 


\section{Abstract}

This study investigates pollution levels, source apportionment, ecological and human health risks associated with toxic metals ( $\mathrm{Pb}, \mathrm{As}$, $\mathrm{Hg}$, $\mathrm{Cr}$, and $\mathrm{Cd}$ ) in road dust from the most populated Dhaka city and a connected major highway in Bangladesh. The mean concentration of $\mathrm{Pb}, \mathrm{Hg}$, and $\mathrm{Cd}$ were $1.3,29.3$, and 13.2 times higher than their corresponding background values with spatially uneven distribution all over the study area. Metal pollution indices, the geoaccumulation index $\left(\mathrm{I}_{\text {geo }}\right)$, NIPI, PI, indicated extreme contamination at many sites depending on local environmental factors. The potential ecological risk ( $\mathrm{E}_{\mathrm{r}}^{\mathrm{i}}$ ) revealed that $84 \%$ and $54 \%$ of samples showed the extreme ecological risk for $\mathrm{Hg}$ and Cd pollution, respectively. On the other hand, the potential ecological risk index (PERI) and nemerow integrated risk index (NIRI) showed that most sampling sites suffered high to extreme ecological risk. Source apportionment using positive matrix factorization (PMF) identified coal combustion and gasoline (50.14\%), traffic exhaust (35.26\%), and industrial and agriculture activity $(14.60 \%)$ were the main source of toxic metals of the study area. Non-carcinogenic health risk indicated that adults are more vulnerable than children, and hazard index $(\mathrm{HI})$ of $\mathrm{Hg}$ for both age groups and $\mathrm{Cd}$ for adults were significantly higher than the safe level. The carcinogenic risk (CR) levels of toxic metals were acceptable $\left(10^{-6}\right.$ to $\left.10^{-4}\right)$, although the maximum limit of $\mathrm{Cr}$ for children and As for adults was close to the unacceptable limit $\left(10^{-4}\right)$. Continual exposure to toxic metals through road dust might develop lifetime cancer risk in local inhabitants.

\section{Introduction}

Road dust is referred to as fine solid particles that are existed in the environments through diverse processes and can accumulate outdoor, especially on cemented roads and hard pavement (Lu et al. 2014; Rahman et al. 2019). Road dust is accounted as hazardous materials due to its high transportability into environmental mediums and poses a potential threat to public health (Khademi et al. 2019; Yesilkanat and Kobya 2021). The dust acts as the sink and source of toxic metals to its corresponding environment (especially soil and air) (Men et al. 2020). The source of toxic metals in dust can be from the resuspension and erosion of surrounding natural environment (soil parent materials) as well as anthropogenic activities such as fossil fuel combustion, traffic activities (e.g., brake lining, tire, and asphalt wear), industrial activities, construction and demolition, waste dumping, and domestic emission (Ali et al. 2017; Hou et al. 2019; Wang et al. 2020). Toxic metals distribution and origin in road dust may depend upon different functional sites of an urban area because of types and intensities of anthropogenic activities (Wang et al. 2016; Li et al. 2017). Spatial analysis is a prerequisite to control and manage pollution through exploring the patterns, hotspots, and sources of toxic metals in road dust (Qin et al. 2020; Wang et al. 2020).

Many large cities in the world are seriously contaminated through toxic metals polluted road dust (Lu et al. 2014; Dehghani et al. 2017; Wang et al. 2020; Yesilkanat and Kobya 2021). Toxic metals are significant environmental contaminants that have harmful, concealed, persistent, bioaccumulation and nonbiodegrade nature (Zhang et al. 2017; Haque et al. 2021b). Human health and the ecosystem have been affected significantly due to metals toxicity and abundance (Jayarathne et al. 2018). Long-term exposure to road dust through ingestion, inhalation, and dermal absorption may cause non-carcinogenic and carcinogenic effects on human health (USEPA 1996, 2011a). Recently, many studies were carried out to determine the source and assess the ecological and human health risk of trace elements exposed through road dust (Rahman et al. 2019; Wang et al. 2020; Jiang et al. 2020; Kolakkandi et al. 2020; Men et al. 2020, 2021; Moghtaderi et al. 2020; Al-Shidi et al. 2020; Aguilera et al. 2021; Yesilkanat and Kobya 2021; Guo et al. 2021; Heidari et al. 2021). Peoples are suffered different health-related complications through exposure to trace elements and other traffic-related pollutants who live near ( $<50 \mathrm{~m})$ or use urban roadways regularly (Duong and Lee 2011; Chen et al. 2017).

Trace elements related to risk are influenced by numerous factors such as toxicity, single and multiple metals concentration (Wiesner et al. 2009). Different types of assessment methods have used, such geo-accumulation index ( $\mathrm{I}_{\text {geo }}$ ), potential ecological risk index (PERI), nemerow integrated pollution index (NIPI), and nemerow integrated risk index (NIRI) to evaluate the pollution status and potential risks (Yang et al. 2011; Men et al. 2018, 2020). Multivariate statistical analysis has been widely used in grouping and identifying the source of pollution in different environmental mediums (Yang et al. 2011). Positive matrix factorization (PMF) is a multivariate statistical model which has been used for source apportionment, and recently many researchers applied it for environmental samples (Jiang et al. 2020; Kolakkandi et al. 2020; Men et al. 2020; Guo et al. 2021; Heidari et al. 2021; Zhu et al. 2021). PMF showed restriction to non-negative values to get more meaningful factors and provide numerical information regarding the contribution of every source type (Men et al. 2020).

In the last two decades, rapid industrialization and urbanization occur in Bangladesh, and trace elements pollution in urban road dust has become a serious public health issue (Rahman et al. 2019). Dhaka is the capital and overpopulated region in Bangladesh, and 13\% of the population lives in the capital (Population Stat 2021). Two-stroke engine vehicles in Dhaka City have been increased several times in the last decade and significantly pollute the atmosphere and road dust (Ahmed and Ishiga 2006). Every day several thousand vehicles are passed through the one of busiest highways named DhakaAricha Highway. It has been supposed that significant augmentation of motor vehicles might impact on the environment in the city and around the highway. Although there is growing interest in recent years in the road dust toxicity on public health. However, very limited attempts have been made to quantify the sources of toxic elements and its possible effect on human health of Bangladesh (Ahmed and Ishiga 2006; Rahman et al. 2019). To the best of our knowledge, this is the first comprehensive study on toxic metal quantification with source identification and ecological and public health risks assessments. Therefore, this study aimed to (1) determine the toxic metal concentration and its distribution pattern within the Dhaka City and Dhaka-Aricha Highway; (2) assess the contamination levels and ecological risk due to toxic metals; (3) source apportionment and their contribution in road dust and finally (4) human health risk assessment due to exposure of toxic metals.

\section{Materials And Methods}

\subsection{Study area and sampling}


Dhaka is the sixth most densely populated city in the world, with a population density of 47,700 citizens per square kilometer (Population Stat 2021). This enormous population has been considered a burden on the traffic, environment, and energy. The city is located mainly in the middle of Bangladesh and interconnected with all districts by roads. The Dhaka-Aricha National Highway connects the south and western part of the country to Dhaka with significant traffic. Day-by-day vehicles and industries are increasing rapidly and result in intensive air pollution (Rahman et al. 2019). On the other hand, the study sites have been surrounded by various industries such as the battery, textile, pharmaceutical, leather, brick kiln, etc., and the agricultural field, especially around the highway. The geology of this area is the Madhupur uplands covered by reddish brown, mottled, well oxidized, ferruginous and calcareous nodules, and compacted Madhupur Clay (Rashid 2003).

This study covered the significant part of Dhaka City and Dhaka-Aricha National highway from where the total 52 samples were collected from thirteen

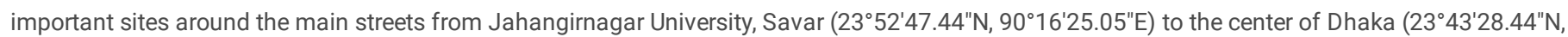
$90^{\circ} 24^{\prime} 18.06 " \mathrm{E}$ ) (Fig. 1). Road dust samples were collected during the humid summer season (April). The sampling locations were uniformly distributed and represented the entire study area. More than $100 \mathrm{~g}$ of road dust samples from the impervious surface were collected by using a polyethylene brush. The samples were stored in sealed zipper polyethylene bags with the appropriate labels and then transferred to the laboratory (Atomic Energy Centre, Dhaka) for further analysis. All the samples were air-dried for two weeks, then sieved with a $1.0 \mathrm{~mm}$ nylon mesh to remove all debris (Wang et al. 2009). Dust samples were also dried for $72 \mathrm{~h}$ at about $45^{\circ} \mathrm{C}$ in an electric oven to remove moisture content and further sieved (74 $\left.\mu \mathrm{m}\right)$ through a nylon mesh. After completely dried, the samples were crushed with an agate mortar and pestle for making fine grain and homogeneous mixer.

\subsection{Sample preparation and analysis}

The concentrations of $\mathrm{Pb}, \mathrm{As}, \mathrm{Hg}, \mathrm{Cr}$, and $\mathrm{Cd}$ in road dust samples were measured by a flame atomic absorption spectrometry (FAAS; Model: AA240FS, Varian, Australia). The samples were prepared by wet digestion methods, according to Islam et al., 2017. All chemical reagents used in the analysis were analytical grade or Suprapure quality and purchased from E. Merck, Germany. For the preparation of all solutions, double deionized water (Milli-Q System, Millipore) was used for every step. The standard solutions were used for instrument calibration, which were prepared by diluting stock solutions of $1000 \mathrm{mg} / \mathrm{l}$ of the respective element. To prepare the sample for metal analysis, $1 \mathrm{~g}$ of road dust samples and standards (IAEA-SL-1 and NIST-1633b) were digested in Teflon vessels with $7 \mathrm{ml} \mathrm{HNO}_{3}(65 \%)$ in a microwave accelerator reaction system (MARS 5, CEM, USA) following standard procedure (USEPA, Method 3051A 2007; Islam et al. 2017). Then the digested solution was filtered by Whatman 41 paper after chilled at room temperature and diluted to $20 \mathrm{ml}$ with double deionized water. Cold vapor atomic absorption spectrometry (CVAAS) (Analytik jena nova AA350) was used for Hg determination., Standard procedures were applied to monitor the instrument performance and data quality, such as replicating samples/standards, method blanks, and spike samples (Islam et al. 2017). Standard reference material (Coal Fly Ash; NIST-1633b) was used for determination of accuracy and precision of the method, and analytical results were found to be \pm $2 \%$ deviation of certified value. The spike recoveries were from 85 to $99 \%$.

\subsection{Metals pollution assessment}

Pollution assessment of road dust is limited, as some methods are reported by researcher although it mostly uses for soil and sediment samples (Awadh 2015; Dehghani et al. 2017; Men et al. 2018). In this study, the geo-accumulation index ( $\mathrm{I}_{\text {geo }}$ ), nemerow integrated pollution index (NIPI), and pollution load index (PLI) were used to calculate contamination levels.

Geo-accumulation index $\left(\mathrm{I}_{\text {geo }}\right)$ was determined by the following equation according to Müller (1979) to assess metals pollution level.

$$
\mathrm{I}_{\text {geo }}=\log _{2}\left(\mathrm{C}_{\mathrm{i}} / 1.5 \mathrm{~B}_{\mathrm{i}}\right)
$$

where $C_{n}$ is the concentration of element i examined in road dust $(\mathrm{mg} / \mathrm{kg}), 1.5$ is the background matrix correction factor due to lithospheric effects, and $B_{i}$ is the geochemical background value of element $\mathrm{i}(\mathrm{mg} / \mathrm{kg})$. Geochemical background of soil and sediment is unavailable for Bangladesh, element concentrations in earth curst reported by Turekian and Wedepohl, (1961) were taken for calculation.

The nemerow integrated pollution index (NIPI) is used to assess the degree of trace element contamination at a particular sampling site. This index considers the mean and maximum values of a single-factor pollution index (PI), and also highlights different pollution degrees (Yang et al. 2011). The pollution load index (PLI) provides a comparative mean that indicates the level of metal pollution in the sample (Xiao et al. 2020; Yesilkanat and Kobya 2021). The NIPI, PI, and PLI can be calculated using following formula:

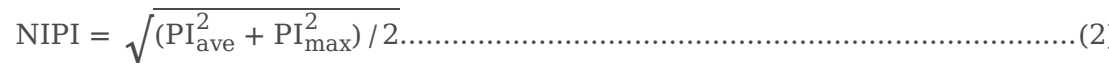

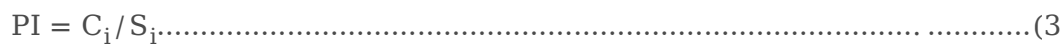

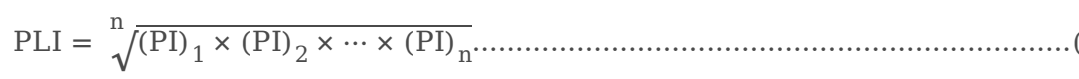

Where $\mathrm{C}_{\mathrm{i}}(\mathrm{mg} / \mathrm{kg})$ is the concentration of element i concentration and $\mathrm{S}_{\mathrm{i}}(\mathrm{mg} / \mathrm{kg})$ is the reference value of element $\mathrm{i}$ (Turekian and Wedepohl 1961). The PI $\mathrm{ave}_{\text {. }}$ and $\mathrm{PI}_{\max }$ are the mean and maximum value of PI, respectively. The classification of above pollution level assessment indexes are listed in Table S1

\subsection{Ecological risk assessment}

Ecological risk assessment methods for road dust also limited, some researcher applied soil/sediment ecological risk assessment methods (Men et al. 2020; Mondal and Singh 2021; Yesilkanat and Kobya 2021) to evaluate the conditions. The potential ecological risk index (PERI) is used to evaluate the potential ecological risk of trace elements (Jiang et al. 2014; Zhao et al. 2015). The formula of PERI determination are as follow: 


$$
\begin{gathered}
\text { PERI }=\sum_{\mathrm{i}=1}^{\mathrm{n}} \mathrm{E}_{\mathrm{r}}^{\mathrm{i}} \cdots \\
\mathrm{E}_{\mathrm{r}}^{\mathrm{i}}=\mathrm{T}_{\mathrm{r}}^{\mathrm{i}} \times \mathrm{C}_{\mathrm{i}} / \mathrm{S}_{\mathrm{i}} \cdots
\end{gathered}
$$

where $\mathrm{E}_{\mathrm{r}}^{\mathrm{i}}$ is the potential ecological risk factor of element $\mathrm{i} ; \mathrm{T}_{\mathrm{r}}^{\mathrm{i}}$ is the toxic response factor of element $\mathrm{i}, \mathrm{r}$ means risk and is not a variable; and $\mathrm{C}_{\mathrm{i}}$ and $\mathrm{S}_{\mathrm{i}}$ are the same as formula (5). The $\mathrm{T}_{\mathrm{r}}^{\mathrm{i}}$ of $\mathrm{Pb}, \mathrm{As}, \mathrm{Hg}, \mathrm{Cr}$, and $\mathrm{Cd}$ was 5, 10, 40, 2, and 30, respectively (Hakanson 1980; Men et al. 2020).

A new risk assessment method called nemerow integrated risk index (NIRI) developed by Men et al., (2020), which was established for integrated ecological risk quantification. The NIRI is the integration of NIPI and PERI, provides more accurate evaluation of multiple trace elements effect on environment. The NIRI can be calculated by following formula:

$$
\mathrm{NIRI}=\sqrt{\left(\mathrm{E}_{\text {rmax }}^{\mathrm{i} 2}+\mathrm{E}_{\text {rave }}^{\mathrm{i} 2}\right) / 2}
$$

where $\mathrm{E}_{\mathrm{rmax}}^{\mathrm{i}}$ and $\mathrm{E}_{\text {rave }}^{\mathrm{i}}$ are the maximum and average value of $\mathrm{E}_{\mathrm{r}}^{\mathrm{i}}$, respectively. The $\mathrm{E}_{\mathrm{r}}^{\mathrm{i}}$ is calculated using formula (7). The classification of above ecological risk indexes are listed in Table S1.

\subsection{Positive Matrix Factorization (PMF)}

Positive Matrix Factorization (PMF) is very effective source identification tools among different multivariate models (Men et al. 2018). In the PMF model, the element concentrations matrix decomposed into contribution matrix and profile matrix. Depend on this decomposition, the emission inventories and the profile information are evaluated, and the sources could be determined. Many researcher have been described detail procedure of PMF model (Kim and Hopke 2007; Yu et al. 2015). The formula is expressed as follow:

$$
x_{i j}=\sum_{k=1}^{p} g_{i k} f_{k j}+e_{i j}
$$

where $\mathrm{x}_{\mathrm{ij}}$ denotes the concentration of elements $\mathrm{j}$ of sample $\mathrm{i}, \mathrm{g}_{\mathrm{ik}}$ is the contribution of factor $\mathrm{k}$ to sample $\mathrm{i}, \mathrm{f}_{\mathrm{kj}}$ is the concentration of elements $\mathrm{j}$ in factor $\mathrm{k}$, eij is the concentration of residuals for the j elements on the i sample, and $\mathrm{p}$ is the factors number. The factors contributions are constrained to be non-negative so that the meaning of operation could be interpreted easily (Bhuiyan et al. 2015).

In the PMF model, the $\mathrm{g}_{\mathrm{ik}}$ and $\mathrm{f}_{\mathrm{kj}}$ are adjusted until the objective function, $\mathrm{Q}$, should be found minimum. The value of $\mathrm{Q}$ reflects the goodness of modeling (Men et al. 2020). The $Q$ is defined in following formula:

$$
Q=\sum_{i=1}^{n} \sum_{j=1}^{m}\left(\frac{e_{i j}}{u_{i j}}\right)^{2} .
$$

where $\mathrm{u}_{\mathrm{ij}}$ is the uncertainly which was calculated according to Kim and Hopke (2007) and Men et al. (2020)

$$
\mathrm{u}_{\mathrm{ij}}=\left\{\begin{array}{c}
\frac{5}{6} \times M D L, \mathrm{x}_{\mathrm{ij}} \leq M D L \\
\sqrt{\left(\sigma_{\mathrm{j}} \times \mathrm{x}_{\mathrm{ij}}\right)^{2}+(\mathrm{MDL})^{2}}, \mathrm{x}_{\mathrm{ij}}>M D L
\end{array}\right.
$$

where $\mathrm{x}_{\mathrm{ij}}$ denotes the concentration of elements $\mathrm{j}$ of sample $\mathrm{i}$ and $\sigma_{\mathrm{j}}$ is the relative standard deviation of the elements $\mathrm{j}$ of sample $\mathrm{i}$.

This study used PMF software (Version 5.0, USEPA) for source identification. The source appointment through PMF model, the sources were determined on the basis of representative elements, literature and the information from the study area.

\subsection{Human health risk assessment}

The non-carcinogenic and carcinogenic risk to human health due to trace elements in road dust were assessed through a model developed by the US Environmental Protection Agency (US EPA, 1996; Men et al., 2018). Two groups of people i.e., adult and children have considered for risk assessment based on their physiological and behavioral differences. The people expose to trace elements through three main pathway: ingestion, inhalation, and dermal contact (Rahman et al. 2019). The average daily intake (ADI) of trace element through these three pathway was assessed using the following formula (USEPA 1989, 1996):

$$
\begin{aligned}
\mathrm{ADI}_{\text {ing }} & =\mathrm{C} \times \frac{\mathrm{IngR} \times \mathrm{EF} \times \mathrm{ED}}{\mathrm{BW} \times \mathrm{AT}} \times 10^{-6} \\
\mathrm{ADI}_{\text {inh }} & =\mathrm{C} \times \frac{\mathrm{InhR} \times \mathrm{EF} \times \mathrm{ED}}{\mathrm{PEF} \times \mathrm{BW} \times \mathrm{AT}} \ldots \ldots \ldots \ldots . .
\end{aligned}
$$




$$
\mathrm{ADI}_{\text {dermal }}=\mathrm{C} \times \frac{\mathrm{SL} \times \mathrm{SA} \times \mathrm{ABS} \times \mathrm{EF} \times \mathrm{ED}}{\mathrm{BW} \times \mathrm{AT}} \times 10^{-6}
$$

where $\mathrm{ADI}_{\mathrm{ing}}, \mathrm{ADI}_{\mathrm{inh}}$, and $\mathrm{ADI} \mathrm{dermal}(\mathrm{mg} / \mathrm{kg})$ are the average daily element intakes through ingestion, inhalation and dermal contact adsorption, respectively, $\mathrm{C}(\mathrm{mg} / \mathrm{kg})$ is the concentration of trace element in road dust, IngR and $\mathrm{InhR}(\mathrm{mg} / \mathrm{kg})$ is the ingestion and inhalation rate, respectively, $\mathrm{EF}$ (days/year) is the exposure frequency, ED (years) is the exposure duration, BW (kg) is the average body weight, AT (days) is the average time, $\mathrm{PEF}\left(\mathrm{m}^{3} / \mathrm{kg}\right.$ ) is the particle emission factor; $\mathrm{SL}\left(\mathrm{mg} / \mathrm{cm}^{2} /\right.$ day) is the skin adherence factor, $\mathrm{SA}\left(\mathrm{cm}^{2}\right)$ is the exposed skin area, and ABS (unitless) the dermal absorption factor. The reference values for all the parameters in the above equations are listed in Table S2.

The non-carcinogenic risk assessed by the following formula (Li et al. 2013):

$$
\begin{aligned}
& \mathrm{HQ}=\mathrm{ADI}_{\mathrm{i}} / \mathrm{R}_{\mathrm{f}} \mathrm{D} . \\
& \mathrm{HI}=\sum \mathrm{HQ}_{\mathrm{i}} \ldots \ldots .
\end{aligned}
$$

where $\mathrm{HQ}$ is hazard quotient or non-carcinogenic risk of single pathway; $\mathrm{R}_{\mathrm{f}} \mathrm{D}$ is the corresponding reference dose of that respective trace elements; $i$ indicates specific pathway (Ferreira-Baptista and De Miguel 2005). $\mathrm{HI}$ is the non-cancer risk of trace elements due to multiple exposure pathways. If $\mathrm{HI}<1$, it indicates no significance non-carcinogenic risk to people. Conversely, if $H I>1$, it indicates the probability of significant non-carcinogenic effects (USEPA 2004). The $\mathrm{R}_{\mathrm{f}} \mathrm{D}$ values of above formula are listed in Table S3.

The assessment of carcinogenic risk (CR) used the following formula (Dehghani et al. 2017):

$$
\begin{aligned}
\mathrm{CR}_{\mathrm{i}} & =\mathrm{ADI}_{\mathrm{i}} \times \mathrm{SF}_{0} . \\
\mathrm{CR} & =\sum \mathrm{CR}_{\mathrm{i}} \ldots \ldots . .
\end{aligned}
$$

where $\mathrm{SF}_{0}$ (unitless) is the carcinogenic slop factor. If $\mathrm{CR}$ value within $10^{-6}$ to $10^{-4}$, it indicates tolerable or acceptable cancer risk. If $\mathrm{CR}>10^{-4}$, it indicates unacceptable cancer risk and when $\mathrm{CR}<10^{-6}$, it indicates no significant cancer risk (USEPA 2011b; Haque et al. 2021b). The values of $\mathrm{SF}_{0}$ are listed in Table S3.

The exposure-point concentration (C) in formula (9)-(11), is considered to yield an estimate of the "reasonable maximum exposure" (USEPA 1989) which is the upper limit of the $95 \%$ confidence interval for the mean ( $95 \% \mathrm{UCL}$ ). Since the most elements concentration in the 52 samples approximate log-normal distributions, the $95 \%$ UCL was calculated by the following formula (USEPA 1996; Rahman et al. 2019):

$$
\mathrm{C}_{95 \% \mathrm{UCL}}=\mathrm{e}\left(\overline{\mathrm{X}}+0.5 \mathrm{~s}^{2}+\frac{\mathrm{S} \times \mathrm{H}}{\sqrt{\mathrm{n-1}}}\right)
$$

where $\overline{\mathrm{X}}$ is the average of log-transform data; s is the standard deviation of log-transform data, $\mathrm{H}$ is the $\mathrm{H}$-statistic (Gilbert 1987), and $\mathrm{n}$ is the number of samples.

\subsection{Spatial analysis}

Inverse Distance Weighted (IDW) tool of ArcGIS 10.3.1 was used in this study for spatial distribution analysis. The IDW appraisals the values of an attribute at un-sampled points using a linear combination of values at sampled points weighted by an inverse function of the distance from the point of interest to the sampled points (Bodrud-Doza et al. 2019). The weights can be expressed as follows:

$$
\lambda_{i}=\frac{1 / d_{i}^{p}}{\sum_{i=1}^{n} 1 / d_{i}^{p}} \ldots
$$

where, $d_{i}$ refers to the distance between $x_{0}$ and $x_{i}, p$ is a power parameter and $n$ indicates the number of sampled points use for the appraisal. The power parameter value significantly affect the accuracy of IDW. Most of the study choose $p$ is 2 for avoiding the complexity and this resulting method is called inverse distance squared (IDS).

\section{Results And Discussion}

\subsection{Toxic metals concentration in road dust}

Concentrations of toxic metals varied significantly among different samples, and the mean and median values of some toxic metals exceeded their background values (Table 1) (Turekian and Wedepohl 1961; Akbor et al. 2020). The mean concentration of Pb, Hg, and Cd were 1.3, 29.3, and 13.2 times higher than that of the respective background concentration, indicating that anthropogenic activities strongly influence on concentration in road dust (Men et al. 2018). However, the mean concentrations of As and Cr have not exceeded the background value. 
Table 1

Concentration of toxic metals in the road dust of the study area and reference cities $(\mathrm{mg} / \mathrm{kg})$.

\begin{tabular}{|c|c|c|c|c|c|c|}
\hline & $\mathrm{Pb}$ & As & $\mathrm{Hg}$ & $\mathrm{Cr}$ & $\mathrm{Cd}$ & \\
\hline Mean & 26.35 & 0.16 & 11.71 & 11.01 & 3.96 & This study \\
\hline Median & 12.00 & 0.16 & 11.20 & 8.40 & 4.96 & \\
\hline Minimum & 1.08 & 0.13 & 0.01 & 6.36 & 0.15 & \\
\hline Maximum & 80.00 & 0.25 & 33.60 & 20.8 & 8.64 & \\
\hline Background & 20 & 13 & 0.4 & 90 & 0.3 & Akbor et al., 2020; Turekian and Wedepohl, 1961 \\
\hline Dhaka (Bangladesh) & 18.9 & 8.1 & - & 144.3 & 11.6 & Rahman et al., 2019 \\
\hline Dhaka (Bangladesh) & 54.26 & - & - & 114.5 & - & Ahmed and Ishiga, 2006 \\
\hline Delhi (India) & 597.9 & - & - & 481.9 & 18.9 & Banerjee, 2003 \\
\hline Beijing, China & 62.29 & 4.08 & 0.26 & 99.50 & 0.51 & Men et al., 2020 \\
\hline Shanghai, China & 246 & 8.73 & 0.16 & 157 & 1.24 & Wang et al., 2009 \\
\hline Egypt & 307 & 6.53 & & 85.7 & 2.98 & Khairy et al., 2011 \\
\hline Shiraz, Iran & 115.71 & 6.58 & - & 67.16 & 0.5 & Keshavarzi et al., 2015 \\
\hline Islamabad, Pakistan & 104 & 2.9 & - & 125 & 5.0 & Faiz et al., 2012 \\
\hline Toronto, Canada & 182.8 & - & - & 197.9 & 0.51 & Nazzal et al., 2013 \\
\hline Kuala Lumpur, Malaysia & 144.30 & - & - & 51.78 & 0.70 & Han et al., 2014 \\
\hline
\end{tabular}

Compared with other Megacities, this study showed low $\mathrm{Pb}$, As, and $\mathrm{Cr}$ concentrations (Table 1). In contrast only Pb showed a higher value than one previous study on Dhaka City, Bangladesh (Rahman et al. 2019). Contrastingly, the concentration of Hg and Cd showed a significant level higher than other cities, except Cd in Dhaka, Bangladesh (Rahman et al. 2019), and Delhi, India (Banerjee 2003).

Among the toxic metals, most of them showed uneven distribution throughout the study area (Fig. 2). The concentrations of $\mathrm{Pb}, \mathrm{Hg}$, and $\mathrm{Cr}$ were found to a greater extent in highways at Savar Area (R1-R5), an uncontrolled industrial and populated area (Haque et al. 2021a). However, some part of the highway was surrounded by agricultural fields (R3-R4). On the other hand, the As, Cd, and Hg were found in high concentration ranges in Dhaka City (R6-R13). The population density and human activities in Dhaka City also greater than in other areas (Rahman et al. 2019). The sampling point R5 (Amin Bazar) in the Dhaka-Aricha Highway is the transition point between Savar Upazila and Dhaka City, which is one of the largest waste landfill sites in Bangladesh and the site demonstrates relatively high toxic metals concentration.

\subsection{Metals pollution assessment}

Based on the pollution assessment results, the $\mathrm{I}_{\text {geo }}$ of $\mathrm{Pb}, \mathrm{As}$, and $\mathrm{Cr}$ revealed that most of the samples were not contaminated (Fig. 3a). According to classification (Table S1), $23 \%$ of samples were showed moderately contaminated by $\mathrm{Pb}$. The $\mathrm{I}_{\text {geo }}$ of $\mathrm{Hg}$ and Cd shows significant toxic metals that were the dominant and key factor of contamination throughout the study area. The $\mathrm{I}_{\text {geo }}$ for $\mathrm{Hg}$ ranges $-6.42-5.30$ and indicating $23 \%$, $31 \%$, and $23 \%$ samples were extremely, heavily to extremely, and heavily contaminated by $\mathrm{Hg}$, respectively. Similarly, the $\mathrm{I}_{\text {geo }}$ of $\mathrm{Cd}$ ranges $-1.58-4.26$ and indicating $15 \%, 38 \%, 8 \%$, and $8 \%$ samples were heavily to extremely, heavily, moderately, and uncontaminated to moderately contaminated, respectively.

The nemerow integrated pollution index (NIPI) indicates how several toxic metals pollute road dust at specific sampling sites by assessing a single metal pollution index (Men et al. 2020). Based on pollution category, index values indicated the severe level of pollution throughout the study area (Yang et al., 2011), where the first quartile (12.11) of the NIPI at all sites was $\sim 4$ times higher than the maximum criterion (NIPI > 3) and the third quartile (33.27) was $~ 11$ times greater than index maximum criterion (Fig. 3b). The majority of the sampling sites showed substantial pollution by toxic metals except for R8 (0.37) and R10 (2.51) (Fig. S1). The mean value of PI was observed highest in the study area for $\mathrm{Hg}$ (29.27) followed by $\mathrm{Cd}$ (13.21), $\mathrm{Pb}$ (1.32), $\mathrm{Cr}(0.12)$, and As (0.01) (Fig. 3c). Based on the PI index (Yang et al. 2011), among the studied samples, 23\%, 85\%, and $70 \%$ of sites were strongly polluted by $\mathrm{Pb}, \mathrm{Hg}$, and $\mathrm{Cd}$, respectively. On the other hand, the PLI values showed that $38 \%$ of sites in the Dhaka-Aricha highway were polluted and exceeded the threshold level (PLI $\geq 1$ ). In contrast, the majority of the samples in Dhaka City were unpolluted ( $\mathrm{PLI}<1$ ) (Fig. S2). These toxic metals might come from traffic exhaust, tire wear, waste landfill, coal combustion, gasoline, and fertilizer and pesticides (Men et al. 2020; Wang et al. 2020; Guo et al. 2021; Mondal and Singh 2021).

\subsection{Ecological Risk Assessment}

The assessment of potential ecological risk $\mathrm{E}_{\mathrm{r}}^{\mathrm{i}}$ of a single toxic metal shows all of the studied sites were at low ecological risk in the environment for $\mathrm{Pb}$, As, and $\mathrm{Cr}\left(\mathrm{E}_{\mathrm{r}}^{\mathrm{i}} \leq 40\right)$ (Fig. 4a). The $\mathrm{E}_{\mathrm{r}}^{\mathrm{i}}$ of $\mathrm{Hg}$ and $\mathrm{Cd}$ demonstrating similar results with $\mathrm{I}_{\mathrm{geo}}$, these toxic metals were key influence factors to cause the potential ecological risk. The primary source of $\mathrm{Cd}$ in road dust could be lubricating oil, diesel fuel, and tire wear (Foti et al. 2017; Men et al. 2018). The study area covered by highway and city, a significant number of vehicles continuously pass through the area and have a great possibility to contaminate through Cd by lubricating oil, diesel fuel, tire, and brake wear (Men et al. 2020; Heidari et al. 2021). Similarly, the Hg might be coming from coal combustion and gasoline 
(Wang et al. 2020), whereas, both the processes are dominated throughout the study area. Among the sampling sites, $84 \%$ and $54 \%$ samples were at extreme ecological risk for $\mathrm{Hg}$ and $\mathrm{Cd}$, respectively, where the values were a significant level higher than the $\mathrm{E}_{\mathrm{r}}^{\mathrm{i}}$ extreme risk category $\left(\mathrm{E}_{\mathrm{r}}^{\mathrm{i}}>320\right)$. On the other hand, $16 \%$ of samples shown considerable to moderate ecological risk for Cd pollution. However, previous studies in different countries also found similar $\mathrm{I}_{\text {geo }}$ and $\mathrm{E}_{\mathrm{r}}^{\mathrm{i}}$ results, such as Muscat (Oman), Beijing (China), Shijiazhuang (China), Baghdad (Iraq), and Egypt (Khairy et al. 2011; Awadh 2015; Men et al. 2018, 2020; Cai and Li 2019; Al-Shidi et al. 2020). Contrastingly, the first and third quartile of PERI were 699 and 2303, respectively, indicates most of the sites were high ecological risk due to toxic metals contamination (Fig. 4b). The PERI values range from $17-2878$, demonstrating that $77 \%$ of sampling sites were at high ecological risk (PERI > 600), and the values were a significance level higher than this risk index. Among the thirteen sites, one high public gathering site (Teacher-Student Center, Dhaka University, R12) shows considerable high ecological risk (300<PERI 6000$)$, and two other low anthropogenic activity sites (R8 and R10) shows comparatively low ecological risk (PERI 150 ) (Fig. S3). The potential ecological risk variation of different sites mostly depend on the localized anthropogenic and other effects.

The NIRI is the new technique for ecological risk assessment, where the integration of NIPI and PERI took place for intensive assessment of study sites. There are basic differences among NIRI, NIPI, and PERI reported in different studies (Men et al. 2020; Heidari et al. 2021). The NIRI values for all samples in the study area ranged from 10.86 to 1702.25 . The value for $85 \%$ of samples were higher than 320 , indicating extreme ecological risk related to studied toxic metals. The first and third quartile of NIRI were 375 and 1329, respectively, indicating sites suffered extreme ecological risk (Fig. 4c). Spatially, the NIRI was higher around Dhaka-Aricha Highway and some locations in Dhaka City (Fig. 4d). Only one site out of 13 was at low risk (NIRI < 40), and another one showed moderate risk $(40<\mathrm{NIRI} \leq 80)$. The difference between NIRI levels and NIPI/PERI levels was significant for all the studied sites. The spatial distribution of risk was systematically related to the spatial intensities of the sources (Fig. 4d, S1 and S3;Xu et al., 2019). Based on NIRI and PERI, most of the sites (81\%) may pose significantly high risk on the local ecology due to the toxic metals pollution by road dust.

This study revealed that surrounding environments of the majority of the sampling sites under stress due to the high risk of $\mathrm{Pb}, \mathrm{Hg}$, and $\mathrm{Cd}$ toxicity. Different indexes showed significant variation in pollution and risk status, although the spatial distribution showed a similar pattern. Among the study area, some sites of Dhaka City and the major portion of Dhaka-Aricha Highway showed significant pollution and ecological risk.

\subsection{Source analysis}

The EPA PMF 5.0 model was extensively used to assign the pollution sources (Men et al. 2020; Xiao et al. 2020; Guo et al. 2021; Heidari et al. 2021; Zhu et al. 2021). In this study, the PMF model shows three main factors that contributing to the accumulation of toxic metal in the road dust. As shown in Fig. $5 \mathrm{a}$, factor 1 contributed $73.05 \%, 53.51 \%$, and $37.31 \%$ to the concentration of $\mathrm{Pb}, \mathrm{As}$, and $\mathrm{Cr}$, respectively. $\mathrm{Pb}$ in the road dust might be accumulated from traffic emission (Men et al. 2018; Xiao et al. 2020). The high concentration of Pb might be associated with industrial activity and As pollution from the use of arsenical pesticides, herbicides, and crop desiccants (Bhuiyan et al. 2015). A previous study reported that these metals might have been released in Dhaka City road dust from the industries of motor-vehicle and metal smelting (Rahman et al. 2019). The major portion around Dhaka-Aricha Highway is the agricultural field, where the farmer uses extensive pesticide and fertilizer for crop growth (Ahmed et al., 2016). The $\mathrm{Cr}$ could release from lather tanning and basification in tannery industries (Bhuiyan et al. 2011). Several lather industries are located near the Dhaka-Aricha Highway and city. Moreover, factor 1 represents industrial and agricultural activity.

Factor 2 mainly contributed to $85.37 \%$ of the total concentration of $\mathrm{Cd}$. The major source of $\mathrm{Cd}$ in road dust might be lubricating oil, diesel fuel, tire, and brake wear (Foti et al. 2017; Men et al. 2020; Heidari et al. 2021). The Cd could be released in the environment easily due to the friction between road and tire of vehicles. Similarly, lubricating oil and diesel fuel leakage can contribute Cd in road dust (Men et al. 2018). Therefore, factor 2 indicates traffic emissions. Based on the analysis of $\mathrm{I}_{\mathrm{geo}}$ and $\mathrm{E}_{\mathrm{r}}^{\mathrm{i}}$, Cd is a significant contributor to road dust pollution and ecological risk.

Factor 3 accounts for $95.43 \%$ of the total concentration of $\mathrm{Hg}$ with negligible contributions of other toxic metals. The source of Hg might be gasoline and coal combustion (Lu et al. 2009; Wang et al. 2020). Fly ash in the atmosphere with metals might come from coal combustion and be deposited in the road dust (Raja et al. 2014). Many brick kilns and other industries (battery, leather, textile, etc.) are located along the highway and near Dhaka city (Guttikunda et al. 2013; Rahman et al. 2019). On the other hand, gasoline pollution was abundant in Dhaka City (Ahmed and Ishiga 2006), and it could be the significant source of $\mathrm{Hg}$ pollution ( $\mathrm{Lu}$ et al. 2009). The brick kilns have been used coal ( $80 \%)$ as a fuel that might pollute the atmosphere and road dust (Guttikunda et al. 2013). On the other hand, day-by-day, the battery electric vehicles are increasing in Bangladesh, especially in urban and suburban areas (Hasan 2020). It could be released a significant amount of $\mathrm{Hg}$ in the environment through battery disposing of the local environment (Hwang et al. 2016). According to the analysis of $\mathrm{I}_{\mathrm{geo}}$ and $\mathrm{E}_{\mathrm{r}}^{\mathrm{i}}, \mathrm{Hg}$ demonstrates the highest contributor among other metals and caused substantial pollution and ecological risk. So the factor 3 most likely represents coal combustion and gasoline as the considerable source.

Among the three contributing factors, coal combustion and gasoline contribute (50.14\%) (Factor 3 ) significant content of metals, although traffic exhaust also contributing most (Fig. 5b). Most of the part of this study covered a highway where brick kilns and different industries are dominated, and in the city along the road, we found extensive urbanization. However, the traffic emission (35.26\%) (Factor 2) is the second contributor of metals and evenly releases pollutants throughout the study area. The previous study on Dhaka City also speculated the same sources as this study (Ahmed and Ishiga 2006; Rahman et al. 2019). Although factor 1 (14.60\%) showed low content, it is also alarming for the people in Dhaka City, especially those who lived along the highway, indicating time to pay attention to the potential exposure to toxic metal content road dust and consequent health risk.

\subsection{Health risk assessment}

Human health risk assessment of toxic metals in the road dust through three exposure pathways (ingestion, inhalation, and dermal contact) was analyzed for children and adults (Table 2). For non-carcinogenic risk, this study revealed that the ingestion of road dust appeared to be the primary exposure route for toxic metals to both age groups, followed by dermal contact and inhalation, respectively (Table 2). Similar results were also reported in many other scientific works 
(Dehghani et al. 2017; Rahman et al. 2019; Heidari et al. 2021; Yesilkanat and Kobya 2021). Both age groups showed the highest $A D I_{\text {ing }}, A D I_{\text {inh }}$ and $A D I_{\text {dermal }}$ for $\mathrm{Pb}$, and lowest $A D I_{\text {ing }}$ and $A D I_{\text {inh }}$ for $A s$, although the lowest $A D I_{\text {dermal }}$ was found for $\mathrm{Cd}$. The hazard quotient (HQ), also known as non-carcinogenic risk for children and adults, was calculated based on reference dose $\left(R_{f} D\right)$ and average daily intake $(A D I)$ of every metal. The $H Q$ values for children and adults were found in the following order of $\mathrm{HQ}_{\text {ing }}>\mathrm{HQ}_{\text {dermal }}>\mathrm{HQ}_{\text {inh }}$ and $\mathrm{HQ}_{\text {dermal }}>\mathrm{HQ}_{\text {ing }}>\mathrm{HQ}_{\text {inh }}$, respectively. Therefore, the result suggested that inhalation of road dust almost negligible compared to ingestion and dermal contact. The HQ order suggested that adults are more susceptible to dermal contact of road dust than children; a previous study in Dhaka City also reported similar findings (Rahman et al. 2019). This study found $\mathrm{HQ}_{\text {dermal }}>1$ in adult groups for $\mathrm{Hg}$ indicating potential non-carcinogenic effects for dermal contact of road dust (USEPA 2004). On the other hand, the HI for all analyzed toxic metals of road dust for both age groups showed the following descending order of $\mathrm{Hg}>\mathrm{Cd}>\mathrm{Cr}>\mathrm{Pb}>\mathrm{As}$. Based on non-carcinogenic effects, it was found that $\mathrm{Hg}$ showed a high $\mathrm{HI}$ (1.06) at the maximum limit than the safe level $(\mathrm{HI}<1)$ for children. Similarly, $\mathrm{Hg}$ and $\mathrm{Cd}$ showed higher $\mathrm{HI}$ values at maximum, mean, and $95 \%$ upper confidence limit than the safe level (1) for adults. This study finding suggested that if children lived around the Dhaka-Aricha Highway and contacted with the road dust at a significant level, then the children might be suffered from impairment of the developing central nervous system, as well as pulmonary and nephrotic damage due to mercury contamination (Counter and Buchanan 2004). Similarly, adult peoples who live close to the study area might be significantly exposed to road dust and suffered from various diseases of the brain, heart, lungs, kidneys, immune system disorder (e.g., neurological, immunological, nephrological) reproductive, cardiac, motor, and even genetic problems due to $\mathrm{Hg}$ poisoning (Kim et al. 2016); and also skeletal damage (osteoporosis), severe kidney damage, chronic renal failure due to $\mathrm{Cd}$ pollution (Haque et al. 2021b). This study also demonstrated that the maximum $\mathrm{Hls}$ values for $\mathrm{Pb}$, As, and $\mathrm{Cr}$ are close to the safe limit (1) (USEPA 2004), indicating that these metals might have contributed to non-cancer risk in both age groups. 
Table 2

Non-carcinogenic and carcinogenic health risk assessment result

\begin{tabular}{|c|c|c|c|c|c|c|c|c|c|c|c|c|c|c|}
\hline \multirow[t]{2}{*}{ Element } & & \multicolumn{13}{|c|}{ Non-carcinogenic Risks } \\
\hline & & \multicolumn{6}{|l|}{ Child } & \multirow{2}{*}{$\begin{array}{l}\text { HI } \\
\text { Ddermal }\end{array}$} & \multicolumn{6}{|l|}{ Adult } \\
\hline Ding & Dinh & Ddermal & HQing & HQinh & HQdermal & Ding & Dinh & & HQing & HQinh & HQdermal & & & CRing \\
\hline \multirow[t]{4}{*}{$\mathrm{Pb}$} & Max & $\begin{array}{l}6.72 \mathrm{E}- \\
04\end{array}$ & $\begin{array}{l}2.82 \mathrm{E}- \\
07\end{array}$ & $\begin{array}{l}2.82 \mathrm{E}- \\
05\end{array}$ & $1.92 \mathrm{E}-01$ & $\begin{array}{l}8.00 \mathrm{E}- \\
05\end{array}$ & $\begin{array}{l}5.38 \mathrm{E}- \\
02\end{array}$ & $\begin{array}{l}2.46 \mathrm{E}- \\
01\end{array}$ & $\begin{array}{l}7.20 \mathrm{E}- \\
05\end{array}$ & $\begin{array}{l}7.41 \mathrm{E}- \\
07\end{array}$ & $2.01 \mathrm{E}-04$ & $\begin{array}{l}2.06 \mathrm{E}- \\
02\end{array}$ & $\begin{array}{l}2.11 \mathrm{E}- \\
04\end{array}$ & $\begin{array}{l}3.83 \mathrm{E}- \\
01\end{array}$ \\
\hline & Min & $\begin{array}{l}8.40 \mathrm{E}- \\
06\end{array}$ & $\begin{array}{l}3.52 \mathrm{E}- \\
09\end{array}$ & $\begin{array}{l}3.53 \mathrm{E}- \\
07\end{array}$ & $2.40 \mathrm{E}-03$ & $\begin{array}{l}1.00 \mathrm{E}- \\
06\end{array}$ & $\begin{array}{l}6.72 \mathrm{E}- \\
04\end{array}$ & $\begin{array}{l}3.07 \mathrm{E}- \\
03\end{array}$ & $\begin{array}{l}9.00 \mathrm{E}- \\
07\end{array}$ & $\begin{array}{l}9.27 \mathrm{E}- \\
09\end{array}$ & $2.51 \mathrm{E}-06$ & $\begin{array}{l}2.57 \mathrm{E}- \\
04\end{array}$ & $\begin{array}{l}2.63 \mathrm{E}- \\
06\end{array}$ & $\begin{array}{l}4.79 \mathrm{E}- \\
03\end{array}$ \\
\hline & mean & $\begin{array}{l}2.21 \mathrm{E}- \\
04\end{array}$ & $\begin{array}{l}9.28 \mathrm{E}- \\
08\end{array}$ & $\begin{array}{l}9.30 \mathrm{E}- \\
06\end{array}$ & $6.33 \mathrm{E}-02$ & $\begin{array}{l}2.64 \mathrm{E}- \\
05\end{array}$ & $\begin{array}{l}1.77 \mathrm{E}- \\
02\end{array}$ & $\begin{array}{l}8.10 \mathrm{E}- \\
02\end{array}$ & $\begin{array}{l}2.37 \mathrm{E}- \\
05\end{array}$ & $\begin{array}{l}2.44 \mathrm{E}- \\
07\end{array}$ & $6.63 \mathrm{E}-05$ & $\begin{array}{l}6.78 \mathrm{E}- \\
03\end{array}$ & $\begin{array}{l}6.94 \mathrm{E}- \\
05\end{array}$ & $\begin{array}{l}1.26 \mathrm{E}- \\
01\end{array}$ \\
\hline & $\begin{array}{l}95 \% \\
\text { UCL }\end{array}$ & $\begin{array}{l}2.30 \mathrm{E}- \\
04\end{array}$ & $\begin{array}{l}9.63 \mathrm{E}- \\
08\end{array}$ & $\begin{array}{l}9.65 \mathrm{E}- \\
06\end{array}$ & $6.57 \mathrm{E}-02$ & $\begin{array}{l}2.74 \mathrm{E}- \\
05\end{array}$ & $\begin{array}{l}1.84 \mathrm{E}- \\
02\end{array}$ & $\begin{array}{l}8.41 \mathrm{E}- \\
02\end{array}$ & $\begin{array}{l}2.46 \mathrm{E}- \\
05\end{array}$ & $\begin{array}{l}2.53 \mathrm{E}- \\
07\end{array}$ & $6.88 \mathrm{E}-05$ & $\begin{array}{l}7.04 \mathrm{E}- \\
03\end{array}$ & $\begin{array}{l}7.20 \mathrm{E}- \\
05\end{array}$ & $\begin{array}{l}1.31 \mathrm{E}- \\
01\end{array}$ \\
\hline \multirow[t]{4}{*}{ As } & Max & $\begin{array}{l}2.10 \mathrm{E}- \\
06\end{array}$ & $\begin{array}{l}8.80 \mathrm{E}- \\
10\end{array}$ & $\begin{array}{l}2.65 \mathrm{E}- \\
06\end{array}$ & 7.00E-03 & $\begin{array}{l}2.92 \mathrm{E}- \\
06\end{array}$ & $\begin{array}{l}2.15 \mathrm{E}- \\
02\end{array}$ & $\begin{array}{l}2.85 \mathrm{E}- \\
02\end{array}$ & $\begin{array}{l}2.25 \mathrm{E}- \\
07\end{array}$ & $\begin{array}{l}2.32 \mathrm{E}- \\
09\end{array}$ & $1.89 \mathrm{E}-05$ & $\begin{array}{l}7.50 \mathrm{E}- \\
04\end{array}$ & $\begin{array}{l}7.70 \mathrm{E}- \\
06\end{array}$ & $\begin{array}{l}3.59 \mathrm{E}- \\
02\end{array}$ \\
\hline & Min & $\begin{array}{l}1.09 \mathrm{E}- \\
06\end{array}$ & $\begin{array}{l}4.58 \mathrm{E}- \\
10\end{array}$ & $\begin{array}{l}1.38 \mathrm{E}- \\
06\end{array}$ & $3.64 \mathrm{E}-03$ & $\begin{array}{l}1.52 \mathrm{E}- \\
06\end{array}$ & $\begin{array}{l}1.12 \mathrm{E}- \\
02\end{array}$ & $\begin{array}{l}1.48 \mathrm{E}- \\
02\end{array}$ & $\begin{array}{l}1.17 \mathrm{E}- \\
07\end{array}$ & $\begin{array}{l}1.20 \mathrm{E}- \\
09\end{array}$ & $9.81 \mathrm{E}-06$ & $\begin{array}{l}3.90 \mathrm{E}- \\
04\end{array}$ & $\begin{array}{l}4.00 \mathrm{E}- \\
06\end{array}$ & $\begin{array}{l}1.87 \mathrm{E}- \\
02\end{array}$ \\
\hline & mean & $\begin{array}{l}1.38 \mathrm{E}- \\
06\end{array}$ & $\begin{array}{l}5.77 \mathrm{E}- \\
10\end{array}$ & $\begin{array}{l}1.73 \mathrm{E}- \\
06\end{array}$ & 4.59E-03 & $\begin{array}{l}1.92 \mathrm{E}- \\
06\end{array}$ & $\begin{array}{l}1.41 \mathrm{E}- \\
02\end{array}$ & $\begin{array}{l}1.87 \mathrm{E}- \\
02\end{array}$ & $\begin{array}{l}1.47 \mathrm{E}- \\
07\end{array}$ & $\begin{array}{l}1.52 \mathrm{E}- \\
09\end{array}$ & $1.24 \mathrm{E}-05$ & $\begin{array}{l}4.92 \mathrm{E}- \\
04\end{array}$ & $\begin{array}{l}5.04 \mathrm{E}- \\
06\end{array}$ & $\begin{array}{l}2.35 \mathrm{E}- \\
02\end{array}$ \\
\hline & $\begin{array}{l}95 \% \\
\text { UCL }\end{array}$ & $\begin{array}{l}1.55 \mathrm{E}- \\
06\end{array}$ & $\begin{array}{l}6.50 \mathrm{E}- \\
10\end{array}$ & $\begin{array}{l}1.96 \mathrm{E}- \\
06\end{array}$ & 5.17E-03 & $\begin{array}{l}2.16 \mathrm{E}- \\
06\end{array}$ & $\begin{array}{l}1.59 \mathrm{E}- \\
02\end{array}$ & $\begin{array}{l}2.11 \mathrm{E}- \\
02\end{array}$ & $\begin{array}{l}1.66 \mathrm{E}- \\
07\end{array}$ & $\begin{array}{l}1.71 \mathrm{E}- \\
09\end{array}$ & $1.39 \mathrm{E}-05$ & $\begin{array}{l}5.54 \mathrm{E}- \\
04\end{array}$ & $\begin{array}{l}5.69 \mathrm{E}- \\
06\end{array}$ & $\begin{array}{l}2.65 \mathrm{E}- \\
02\end{array}$ \\
\hline \multirow[t]{4}{*}{$\mathrm{Hg}$} & Max & $\begin{array}{l}1.98 \mathrm{E}- \\
04\end{array}$ & $\begin{array}{l}8.31 \mathrm{E}- \\
08\end{array}$ & $\begin{array}{l}8.33 \mathrm{E}- \\
06\end{array}$ & $6.61 \mathrm{E}-01$ & $\begin{array}{l}9.70 \mathrm{E}- \\
04\end{array}$ & $\begin{array}{l}3.97 \mathrm{E}- \\
01\end{array}$ & $\begin{array}{l}1.06 \mathrm{E}+ \\
00\end{array}$ & $\begin{array}{l}2.12 \mathrm{E}- \\
05\end{array}$ & $\begin{array}{l}2.19 \mathrm{E}- \\
07\end{array}$ & 5.93E-05 & $\begin{array}{l}7.08 \mathrm{E}- \\
02\end{array}$ & $\begin{array}{l}2.55 \mathrm{E}- \\
03\end{array}$ & $\begin{array}{l}2.83 \mathrm{E} \\
+00\end{array}$ \\
\hline & Min & $\begin{array}{l}8.40 \mathrm{E}- \\
08\end{array}$ & $\begin{array}{l}3.52 \mathrm{E}- \\
11\end{array}$ & $\begin{array}{l}3.53 \mathrm{E}- \\
09\end{array}$ & $2.80 \mathrm{E}-04$ & $\begin{array}{l}4.11 \mathrm{E}- \\
07\end{array}$ & $\begin{array}{l}1.68 \mathrm{E}- \\
04\end{array}$ & $\begin{array}{l}4.49 \mathrm{E}- \\
04\end{array}$ & $\begin{array}{l}9.00 \mathrm{E}- \\
09\end{array}$ & $\begin{array}{l}9.27 \mathrm{E}- \\
11\end{array}$ & $2.51 \mathrm{E}-08$ & $\begin{array}{l}3.00 \mathrm{E}- \\
05\end{array}$ & $\begin{array}{l}1.08 \mathrm{E}- \\
06\end{array}$ & $\begin{array}{l}1.20 \mathrm{E}- \\
03\end{array}$ \\
\hline & mean & $\begin{array}{l}9.84 \mathrm{E}- \\
05\end{array}$ & $\begin{array}{l}4.12 \mathrm{E}- \\
08\end{array}$ & $\begin{array}{l}4.13 \mathrm{E}- \\
06\end{array}$ & $3.28 \mathrm{E}-01$ & $\begin{array}{l}4.81 \mathrm{E}- \\
04\end{array}$ & $\begin{array}{l}1.97 \mathrm{E}- \\
01\end{array}$ & $\begin{array}{l}5.25 \mathrm{E}- \\
01\end{array}$ & $\begin{array}{l}1.05 E- \\
05\end{array}$ & $\begin{array}{l}1.09 \mathrm{E}- \\
07\end{array}$ & $2.94 \mathrm{E}-05$ & $\begin{array}{l}3.51 \mathrm{E}- \\
02\end{array}$ & $\begin{array}{l}1.27 \mathrm{E}- \\
03\end{array}$ & $\begin{array}{l}\text { 1.40E } \\
+00\end{array}$ \\
\hline & $\begin{array}{l}95 \% \\
\text { UCL }\end{array}$ & $\begin{array}{l}9.85 \mathrm{E}- \\
05\end{array}$ & $\begin{array}{l}4.13 \mathrm{E}- \\
08\end{array}$ & $\begin{array}{l}4.14 \mathrm{E}- \\
06\end{array}$ & $3.28 \mathrm{E}-01$ & $\begin{array}{l}4.82 \mathrm{E}- \\
04\end{array}$ & $\begin{array}{l}1.97 \mathrm{E}- \\
01\end{array}$ & $\begin{array}{l}5.26 \mathrm{E}- \\
01\end{array}$ & $\begin{array}{l}1.05 \mathrm{E}- \\
05\end{array}$ & $\begin{array}{l}1.09 \mathrm{E}- \\
07\end{array}$ & $2.95 \mathrm{E}-05$ & $\begin{array}{l}3.52 \mathrm{E}- \\
02\end{array}$ & $\begin{array}{l}1.27 \mathrm{E}- \\
03\end{array}$ & $\begin{array}{l}1.40 \mathrm{E} \\
+00\end{array}$ \\
\hline \multirow[t]{4}{*}{$\mathrm{Cr}$} & Max & $\begin{array}{l}1.69 \mathrm{E}- \\
04\end{array}$ & $\begin{array}{l}7.07 \mathrm{E}- \\
08\end{array}$ & $\begin{array}{l}7.09 \mathrm{E}- \\
06\end{array}$ & $5.62 \mathrm{E}-02$ & $\begin{array}{l}2.47 \mathrm{E}- \\
03\end{array}$ & $\begin{array}{l}1.18 \mathrm{E}- \\
01\end{array}$ & $\begin{array}{l}1.77 \mathrm{E}- \\
01\end{array}$ & $\begin{array}{l}1.81 \mathrm{E}- \\
05\end{array}$ & $\begin{array}{l}1.86 \mathrm{E}- \\
07\end{array}$ & $5.05 \mathrm{E}-05$ & $\begin{array}{l}6.03 \mathrm{E}- \\
03\end{array}$ & $\begin{array}{l}6.51 \mathrm{E}- \\
03\end{array}$ & $\begin{array}{l}8.41 \mathrm{E}- \\
01\end{array}$ \\
\hline & Min & $\begin{array}{l}5.34 \mathrm{E}- \\
05\end{array}$ & $\begin{array}{l}2.24 \mathrm{E}- \\
08\end{array}$ & $\begin{array}{l}2.24 \mathrm{E}- \\
06\end{array}$ & $1.78 \mathrm{E}-02$ & $\begin{array}{l}7.83 \mathrm{E}- \\
04\end{array}$ & $\begin{array}{l}3.74 \mathrm{E}- \\
02\end{array}$ & $\begin{array}{l}5.60 \mathrm{E}- \\
02\end{array}$ & $\begin{array}{l}5.73 \mathrm{E}- \\
06\end{array}$ & $\begin{array}{l}5.89 \mathrm{E}- \\
08\end{array}$ & $1.60 \mathrm{E}-05$ & $\begin{array}{l}1.91 \mathrm{E}- \\
03\end{array}$ & $\begin{array}{l}2.06 \mathrm{E}- \\
03\end{array}$ & $\begin{array}{l}2.67 \mathrm{E}- \\
01\end{array}$ \\
\hline & mean & $\begin{array}{l}9.25 \mathrm{E}- \\
05\end{array}$ & $\begin{array}{l}3.88 \mathrm{E}- \\
08\end{array}$ & $\begin{array}{l}3.88 \mathrm{E}- \\
06\end{array}$ & $3.08 \mathrm{E}-02$ & $\begin{array}{l}1.36 \mathrm{E}- \\
03\end{array}$ & $\begin{array}{l}6.47 \mathrm{E}- \\
02\end{array}$ & $\begin{array}{l}9.69 \mathrm{E}- \\
02\end{array}$ & $\begin{array}{l}9.91 \mathrm{E}- \\
06\end{array}$ & $\begin{array}{l}1.02 \mathrm{E}- \\
07\end{array}$ & 2.77E-05 & $\begin{array}{l}3.30 \mathrm{E}- \\
03\end{array}$ & $\begin{array}{l}3.57 \mathrm{E}- \\
03\end{array}$ & $\begin{array}{l}4.61 \mathrm{E}- \\
01\end{array}$ \\
\hline & $\begin{array}{l}95 \% \\
\text { UCL }\end{array}$ & $\begin{array}{l}1.16 \mathrm{E}- \\
04\end{array}$ & $\begin{array}{l}4.87 \mathrm{E}- \\
08\end{array}$ & $\begin{array}{l}4.88 \mathrm{E}- \\
06\end{array}$ & 3.87E-02 & $\begin{array}{l}1.70 \mathrm{E}- \\
03\end{array}$ & $\begin{array}{l}8.13 \mathrm{E}- \\
02\end{array}$ & $\begin{array}{l}1.22 \mathrm{E}- \\
01\end{array}$ & $\begin{array}{l}1.24 \mathrm{E}- \\
05\end{array}$ & $\begin{array}{l}1.28 \mathrm{E}- \\
07\end{array}$ & 3.47E-05 & $\begin{array}{l}4.15 \mathrm{E}- \\
03\end{array}$ & $\begin{array}{l}4.48 \mathrm{E}- \\
03\end{array}$ & $\begin{array}{l}5.79 \mathrm{E}- \\
01\end{array}$ \\
\hline \multirow[t]{3}{*}{$\mathrm{Cd}$} & Max & $\begin{array}{l}7.26 \mathrm{E}- \\
05\end{array}$ & $\begin{array}{l}3.04 \mathrm{E}- \\
08\end{array}$ & $\begin{array}{l}3.05 \mathrm{E}- \\
06\end{array}$ & $7.26 \mathrm{E}-02$ & $\begin{array}{l}3.04 \mathrm{E}- \\
05\end{array}$ & $\begin{array}{l}3.05 \mathrm{E}- \\
01\end{array}$ & $\begin{array}{l}3.78 \mathrm{E}- \\
01\end{array}$ & $\begin{array}{l}7.78 \mathrm{E}- \\
06\end{array}$ & $\begin{array}{l}8.01 \mathrm{E}- \\
08\end{array}$ & 2.17E-05 & $\begin{array}{l}7.78 \mathrm{E}- \\
03\end{array}$ & $\begin{array}{l}8.01 \mathrm{E}- \\
05\end{array}$ & $\begin{array}{l}2.17 E \\
+00\end{array}$ \\
\hline & Min & $\begin{array}{l}1.26 \mathrm{E}- \\
06\end{array}$ & $\begin{array}{l}5.28 \mathrm{E}- \\
10\end{array}$ & $\begin{array}{l}5.29 \mathrm{E}- \\
08\end{array}$ & $1.26 \mathrm{E}-03$ & $\begin{array}{l}5.28 \mathrm{E}- \\
07\end{array}$ & $\begin{array}{l}5.29 \mathrm{E}- \\
03\end{array}$ & $\begin{array}{l}6.55 \mathrm{E}- \\
03\end{array}$ & $\begin{array}{l}1.35 \mathrm{E}- \\
07\end{array}$ & $\begin{array}{l}1.39 \mathrm{E}- \\
09\end{array}$ & 3.77E-07 & $\begin{array}{l}1.35 \mathrm{E}- \\
04\end{array}$ & $\begin{array}{l}1.39 \mathrm{E}- \\
06\end{array}$ & $\begin{array}{l}3.77 \mathrm{E}- \\
02\end{array}$ \\
\hline & mean & $\begin{array}{l}3.33 \mathrm{E}- \\
05\end{array}$ & $\begin{array}{l}1.40 \mathrm{E}- \\
08\end{array}$ & $\begin{array}{l}1.40 \mathrm{E}- \\
06\end{array}$ & 3.33E-02 & $\begin{array}{l}1.40 \mathrm{E}- \\
05\end{array}$ & $\begin{array}{l}1.40 \mathrm{E}- \\
01\end{array}$ & $\begin{array}{l}1.73 E- \\
01\end{array}$ & $\begin{array}{l}3.57 \mathrm{E}- \\
06\end{array}$ & $\begin{array}{l}3.67 \mathrm{E}- \\
08\end{array}$ & $9.96 \mathrm{E}-06$ & $\begin{array}{l}3.57 \mathrm{E}- \\
03\end{array}$ & $\begin{array}{l}3.67 \mathrm{E}- \\
05\end{array}$ & $\begin{array}{l}9.96 \mathrm{E}- \\
01\end{array}$ \\
\hline
\end{tabular}

Since $\mathrm{Pb}, \mathrm{As}, \mathrm{Cr}$ and Cd, are classified as class I cancer-causing agents (IARC 2011), carcinogenic risk (CR) is evaluated based on the concentration of these toxic metals. Lifetime exposure to carcinogenic agents can develop any type of cancer in an individual (Haque et al. 2021a). This study could not consider Hg, $\mathrm{Cd}$ (dermal), and $\mathrm{Cr}$ (dermal) for risk assessment due to the unavailable of cancer slope factor $\left(\mathrm{SF}_{0}\right)$ values. The results of cancer risk for possible exposure pathways are shown in Table 1. The average CR values of three exposure routes have been suggested that ingestion for children and dermal contact for adults is the most significant routes for cancer risk. The average $\mathrm{CR}$ values for children and adults were found in following order of $\mathrm{Cr}(4.79 \mathrm{E}-05)>\mathrm{Cd}(1.27 \mathrm{E}-05)>\mathrm{As}$ $(8.42 \mathrm{E}-06)>\mathrm{Pb}(1.89 \mathrm{E}-06)$ and $\mathrm{As}(4.55 \mathrm{E}-05)>\mathrm{Cr}(9.24 \mathrm{E}-06)>\mathrm{Cd}(1.59 \mathrm{E}-06)>\mathrm{Pb}(2.12 \mathrm{E}-07)$, respectively. This study revealed that the average $\mathrm{CR}$ values of all toxic metals (except $\mathrm{Pb}$ for adults) in road dust were fallen within the range of acceptable or tolerable cancer risk (10 ${ }^{-6}$ to $10^{-4}$ ) (USEPA $\left.2011 \mathrm{~b}\right)$. The $\mathrm{CR}$ of $\mathrm{Pb}$ for adults was (range: 8.06E-09-6.45E-07) lower than no cancer risk value $\left(<10^{-6}\right)$, which indicates the adults would pose negligible cancer risk due to $\mathrm{Pb}$ pollution. Regarding the cancer risk, this study observed that the maximum CRs level of $\mathrm{Cr}$ for children and As for adults was very close to unacceptable cancer risk $\left(10^{-4}\right)$ which suggested that local inhabitants might pose significant cancer risk if they expose continuously to road dust. A previous study on road dust in Dhaka City also focused on $\mathrm{Cr}$ and As induced cancer risk for inhabitants (Rahman et al. 2019). Therefore, it could be suggested that As, Cr and Cd in road dust of Dhaka City and Dhaka-Aricha Highway pose a detrimental threat of cancer risk. 


\section{Conclusion}

The mean concentration of toxic metals, except As and Cd, were significantly higher than the corresponding background values. Spatial distribution of toxic metals revealed that $\mathrm{Pb}, \mathrm{Hg}$ and $\mathrm{Cr}$ were mostly dominated in suburban areas of the highway. The $\mathrm{I}_{\text {geo }}$ indicated low to extremely contamination of toxic metals of the sampling sites. Similarly, the NIPI, PI and PLI demonstrated that road dusts were unpolluted to strongly polluted by toxic metals depend on local environmental factors. The ecological risk indices, $\mathrm{E}_{\mathrm{r}}^{\mathrm{i}}$, PERI and NIRI showed low to extreme ecological risk throughout the study area, and the highway was the most vulnerable than city., The $\mathrm{Hg}, \mathrm{Cd}$, and $\mathrm{Pb}$ were the influential toxic metals among studied metals to calculate the above indices. The PMF analysis showed three main factors that influence metals accumulation. Factor 1 ( $\mathrm{Pb}, \mathrm{As}$, and $\mathrm{Cr}$ ) indicates industrial and agriculture activity (14.60\%), factor 2 (Cd) indicates traffic exhaust (35.26\%), and factor $3(\mathrm{Hg})$ indicates coal combustion and gasoline (50.14\%). Among the sources, coal combustion and gasoline was the dominated factor because of abundant brick kiln and gasoline engine throughout the study area. Health risk assessment suggested that inhalation of road dust mostly negligible compare to ingesting and dermal contact, and adults are more susceptible than children. The HI value for Hg was higher than the safe limit for both age groups, whereas $\mathrm{HI}$ for $\mathrm{Cd}$ showed higher than 1 for adults only. Therefore, the inhabitant of the study area might be suffered from noncarcinogenic health risks due to $\mathrm{Hg}$ and $\mathrm{Cd}$. The cancer risk level for all the studied toxic metals, except $\mathrm{Pb}$ for adults, were within the acceptable range (10 6 to $\left.10^{-4}\right)$. In comparison, the $\mathrm{CR}$ of $\mathrm{Pb}$ for adults showed negligible risk $\left(<10^{-6}\right)$. However, continual lifetime exposure to toxic metals by road dust might be developed cancer in the local inhabitant.

\section{Declarations}

\section{Ethics approval and consent to participate}

Not applicable

\section{Consent for publication}

Not applicable

\section{Availability of data and material}

All data sources described in this study are directed at the corresponding author.

\section{Declaration of Competing Interest}

The authors declare that they have no known competing financial interests or personal relationships that could have appeared to influence the work reported in this paper.

\section{Funding}

This research did not receive any specific grant from funding agencies in the public, commercial, or not-for-profit sectors.

\section{Author Contribution}

Md. Morshedul Haque: Writing - Original Draft, Formal analysis, Visualization

Sajin Sultana: Investigation and Data Curation

Nahin Mostofa Niloy: Data Curation

Shamshad B. Quraishi: Resources

Shafi M. Tareq: Conceptualization, Review \& Editing, Supervision

\section{Acknowledgement}

The authors would like to acknowledge Analytical Chemistry Laboratory, Chemistry Division, Atomic Energy Center, Dhaka, for providing logistic and technical support. Sajin Sultana would like to extend gratitude to Juel Mahmud for his support during sample collections and A.K.M Atique Ullah for his kind support and suggestions during the experiment at Atomic Energy Center, Dhaka.

\section{References}

1. Aguilera A, Bautista F, Gutiérrez-Ruiz M et al (2021) Heavy metal pollution of street dust in the largest city of Mexico, sources and health risk assessment. Environ Monit Assess 193:. https://doi.org/10.1007/s10661-021-08993-4

2. Ahmed F, Ishiga H (2006) Trace metal concentrations in street dusts of Dhaka city, Bangladesh. Atmos Environ 40:3835-3844. https://doi.org/10.1016/j.atmosenv.2006.03.004

3. Akbor MA, Rahman MM, Bodrud-Doza M et al (2020) Metal pollution in water and sediment of the Buriganga river, Bangladesh: An ecological risk perspective. Desalin Water Treat 193:284-301. https://doi.org/10.5004/dwt.2020.25805 
4. Al-Shidi HK, Al-Reasi HA, Sulaiman H (2020) Heavy metals levels in road dust from Muscat, Oman: relationship with traffic volumes, and ecological and health risk assessments. Int J Environ Health Res 00:1-13. https://doi.org/10.1080/09603123.2020.1751806

5. Ali MU, Liu G, Yousaf B et al (2017) Pollution characteristics and human health risks of potentially (eco)toxic elements (PTEs) in road dust from metropolitan area of Hefei, China. Chemosphere 181:111-121. https://doi.org/10.1016/j.chemosphere.2017.04.061

6. Awadh SM (2015) Cd, Ni, and Pb distribution and pollution assessment in roadside dust from Baghdad City and Western Iraqi Desert. Arab J Geosci 8:315-323. https://doi.org/10.1007/s12517-013-1204-y

7. Banerjee ADK (2003) Heavy metal levels and solid phase speciation in street dusts of Delhi, India. Environ Pollut 123:95-105. https://doi.org/10.1016/S0269-7491(02)00337-8

8. Bhuiyan MAH, Dampare SB, Islam MA, Suzuki S (2015) Source apportionment and pollution evaluation of heavy metals in water and sediments of Buriganga River, Bangladesh, using multivariate analysis and pollution evaluation indices. Environ Monit Assess 187:4075. https://doi.org/10.1007/s10661-014-4075-0

9. Bhuiyan MAH, Suruvi NI, Dampare SB et al (2011) Investigation of the possible sources of heavy metal contamination in lagoon and canal water in the tannery industrial area in Dhaka, Bangladesh. Environ Monit Assess 175:633-649. https://doi.org/10.1007/s10661-010-1557-6

10. Bodrud-Doza M, Bhuiyan MAH, Islam SMDU et al (2019) Hydrogeochemical investigation of groundwater in Dhaka City of Bangladesh using GIS and multivariate statistical techniques. Groundw Sustain Dev 8:226-244. https://doi.org/10.1016/j.gsd.2018.11.008

11. Cai K, Li C (2019) Street dust heavy metal pollution source apportionment and sustainable management in a typical city-shijiazhuang, china. Int J Environ Res Public Health 16:. https://doi.org/10.3390/ijerph16142625

12. Chen H, Kwong JC, Copes R et al (2017) Living near major roads and the incidence of dementia, Parkinson's disease, and multiple sclerosis: a populationbased cohort study. Lancet 389:718-726. https://doi.org/10.1016/S0140-6736(16)32399-6

13. Counter SA, Buchanan LH (2004) Mercury exposure in children: A review. Toxicol Appl Pharmacol 198:209-230. https://doi.org/10.1016/j.taap.2003.11.032

14. Dehghani S, Moore F, Keshavarzi B, Hale BA (2017) Health risk implications of potentially toxic metals in street dust and surface soil of Tehran, Iran. Ecotoxicol Environ Saf 136:92-103. https://doi.org/10.1016/j.ecoenv.2016.10.037

15. Duong TTT, Lee BK (2011) Determining contamination level of heavy metals in road dust from busy traffic areas with different characteristics. J Environ Manage 92:554-562. https://doi.org/10.1016/j.jenvman.2010.09.010

16. Faiz Y, Siddique N, Tufail M (2012) Pollution level and health risk assessment of road dust from an expressway. J Environ Sci Heal Part A 47:818-829. https://doi.org/10.1080/10934529.2012.664994

17. Ferreira-Baptista L, De Miguel E (2005) Geochemistry and risk assessment of street dust in Luanda, Angola: A tropical urban environment. Atmos Environ 39:4501-4512. https://doi.org/10.1016/j.atmosenv.2005.03.026

18. Foti L, Dubs F, Gignoux J et al (2017) Trace element concentrations along a gradient of urban pressure in forest and lawn soils of the Paris region (France). Sci Total Environ 598:938-948. https://doi.org/10.1016/j.scitotenv.2017.04.111

19. Gilbert RO (1987) Statistical Methods for Environmental Pollution Monitoring. Van Nostrand Reinhold, New York

20. Guo G, Zhang D, Yuntao, Wang (2021) Source apportionment and source-specific health risk assessment of heavy metals in size-fractionated road dust from a typical mining and smelting area, Gejiu, China. Environ Sci Pollut Res 28:9313-9326. https://doi.org/10.1007/s11356-020-11312-y

21. Guttikunda SK, Begum BA, Wadud Z (2013) Particulate pollution from brick kiln clusters in the Greater Dhaka region, Bangladesh. Air Qual Atmos Heal 6:357-365. https://doi.org/10.1007/s11869-012-0187-2

22. Hakanson L (1980) An ecological risk index for aquatic pollution control. A sedimentological approach. Water Res 14:975-1001. https://doi.org/10.1016/0043-1354(80)90143-8

23. Han NMM, Latif MT, Othman M et al (2014) Composition of selected heavy metals in road dust from Kuala Lumpur city centre. Environ Earth Sci 72:849859. https://doi.org/10.1007/s12665-013-3008-5

24. Haque MM, Hossain N, Jolly YN, Tareq SM (2021a) Probabilistic health risk assessment of toxic metals in chickens from the largest production areas of Dhaka, Bangladesh. Environ Sci Pollut Res. https://doi.org/https://doi.org/10.1007/s11356-021-13534-0

25. Haque MM, Niloy NM, Khirul MA et al (2021b) Appraisal of probabilistic human health risks of heavy metals in vegetables from industrial. non-industrial arsenic contaminated areas of Bangladesh Heliyon 7:e06309. https://doi.org/10.1016/j.heliyon.2021.e06309

26. Hasan ASMM (2020) Electric Rickshaw Charging Stations as Distributed Energy Storages for Integrating Intermittent Renewable Energy Sources: A Case of Bangladesh. Energies 13:6119. https://doi.org/10.3390/en13226119

27. Heidari M, Darijani T, Alipour V (2021) Heavy metal pollution of road dust in a city and its highly polluted suburb; quantitative source apportionment and source-specific ecological and health risk assessment. Chemosphere 273:129656. https://doi.org/10.1016/j.chemosphere.2021.129656

28. Hou S, Zheng N, Tang L et al (2019) Pollution characteristics, sources, and health risk assessment of human exposure to Cu, Zn, Cd and Pb pollution in urban street dust across China between 2009 and 2018. Environ Int 128:430-437. https://doi.org/10.1016/j.envint.2019.04.046

29. Hwang HM, Fiala MJ, Park D, Wade TL (2016) Review of pollutants in urban road dust and stormwater runoff: part 1. Heavy metals released from vehicles. Int J Urban Sci 20:334-360. https://doi.org/10.1080/12265934.2016.1193041

30. IARC (2011) International agency for research on cancer. Agents Classified by the IARC Monographs. 1-102

31. Islam MA, Al-mamun A, Hossain F et al (2017) Contamination and ecological risk assessment of trace elements in sediments of the rivers of Sundarban mangrove forest, Bangladesh. Mar Pollut Bull 124:356-366. https://doi.org/10.1016/j.marpolbul.2017.07.059 
32. Jayarathne A, Egodawatta P, Ayoko GA, Goonetilleke A (2018) Assessment of ecological and human health risks of metals in urban road dust based on geochemical fractionation and potential bioavailability. Sci Total Environ 635:1609-1619. https://doi.org/10.1016/j.scitotenv.2018.04.098

33. Jiang HH, Cai LM, Wen HH, Luo J (2020) Characterizing pollution and source identification of heavy metals in soils using geochemical baseline and PMF approach. Sci Rep 10:1-11. https://doi.org/10.1038/s41598-020-63604-5

34. Jiang X, Lu WX, Zhao HQ et al (2014) Potential ecological risk assessment and prediction of soil heavy-metal pollution around coal gangue dump. Nat Hazards Earth Syst Sci 14:1599-1610. https://doi.org/10.5194/nhess-14-1599-2014

35. Keshavarzi B, Tazarvi Z, Rajabzadeh MA, Najmeddin A (2015) Chemical speciation, human health risk assessment and pollution level of selected heavy metals in urban street dust of Shiraz, Iran. Elsevier Ltd

36. Khademi H, Gabarrón M, Abbaspour A et al (2019) Environmental impact assessment of industrial activities on heavy metals distribution in street dust and soil. Chemosphere 217:695-705. https://doi.org/10.1016/j.chemosphere.2018.11.045

37. Khairy MA, Barakat AO, Mostafa AR, Wade TL (2011) Multielement determination by flame atomic absorption of road dust samples in Delta Region, Egypt. Microchem J 97:234-242. https://doi.org/10.1016/j.microc.2010.09.012

38. Kim E, Hopke PK (2007) Comparison between sample-species specific uncertainties and estimated uncertainties for the source apportionment of the speciation trends network data. Atmos Environ 41:567-575. https://doi.org/10.1016/j.atmosenv.2006.08.023

39. Kim KH, Kabir E, Jahan SA (2016) A review on the distribution of Hg in the environment and its human health impacts. J Hazard Mater 306:376-385. https://doi.org/10.1016/j.jhazmat.2015.11.031

40. Kolakkandi V, Sharma B, Rana A et al (2020) Spatially resolved distribution, sources and health risks of heavy metals in size-fractionated road dust from 57 sites across megacity Kolkata, India. Sci Total Environ 705:135805. https://doi.org/10.1016/j.scitotenv.2019.135805

41. Li H, Qian X, Hu W et al (2013) Chemical speciation and human health risk of trace metals in urban street dusts from a metropolitan city, Nanjing, SE China. Sci Total Environ 456-457:212-221. https://doi.org/10.1016/j.scitotenv.2013.03.094

42. Li HH, Chen LJ, Yu L et al (2017) Pollution characteristics and risk assessment of human exposure to oral bioaccessibility of heavy metals via urban street dusts from different functional areas in Chengdu, China. Sci Total Environ 586:1076-1084. https://doi.org/10.1016/j.scitotenv.2017.02.092

43. Lu X, Li LY, Wang L et al (2009) Contamination assessment of mercury and arsenic in roadway dust from Baoji, China. Atmos Environ 43:2489-2496. https://doi.org/10.1016/j.atmosenv.2009.01.048

44. Lu X, Wu X, Wang Y et al (2014) Risk assessment of toxic metals in street dust from a medium-sized industrial city of China. Ecotoxicol Environ Saf 106:154-163. https://doi.org/10.1016/j.ecoenv.2014.04.022

45. Men C, Liu R, Xu F et al (2018) Pollution characteristics, risk assessment, and source apportionment of heavy metals in road dust in Beijing, China. Sci Total Environ 612:138-147. https://doi.org/10.1016/j.scitotenv.2017.08.123

46. Men C, Liu R, Xu L et al (2020) Source-specific ecological risk analysis and critical source identification of heavy metals in road dust in Beijing, China. J Hazard Mater 388:. https://doi.org/10.1016/j.jhazmat.2019.121763

47. Men C, Wang Y, Liu R et al (2021) Temporal variations of levels and sources of health risk associated with heavy metals in road dust in Beijing from May 2016 to April 2018. Chemosphere 270:129434. https://doi.org/10.1016/j.chemosphere.2020.129434

48. Moghtaderi T, Alamdar R, Rodríguez-Seijo A et al (2020) Ecological risk assessment and source apportionment of heavy metal contamination in urban soils in Shiraz, Southwest Iran. Arab J Geosci 13:. https://doi.org/10.1007/s12517-020-05787-9

49. Mondal S, Singh G (2021) Pollution evaluation, human health effect and tracing source of trace elements on road dust of Dhanbad, a highly polluted industrial coal belt of India. Environ Geochem Health 0123456789: https://doi.org/10.1007/s10653-020-00785-y

50. Müller G (1979) Schwermetalle in den sediments des Rheins- Veranderungen seitt 1971. Umschan 79:778-783

51. Nazzal Y, Rosen MA, Al-Rawabdeh AM (2013) Assessment of metal pollution in urban road dusts from selected highways of the Greater Toronto Area in Canada. Environ Monit Assess 185:1847-1858. https://doi.org/10.1007/s10661-012-2672-3

52. Population Stat (2021) World population data. Dhaka, Bangladesh Population. https://populationstat.com/bangladesh/dhaka. Accessed 30 Apr 2021

53. Qin H, Hu T, Zhai Y et al (2020) The improved methods of heavy metals removal by biosorbents: A review. Elsevier

54. Rahman MS, Khan MDH, Jolly YN et al (2019) Assessing risk to human health for heavy metal contamination through street dust in the Southeast Asian Megacity: Dhaka, Bangladesh. Sci Total Environ 660:1610-1622. https://doi.org/10.1016/j.scitotenv.2018.12.425

55. Raja R, Nayak AK, Rao KS et al (2014) Effect of Fly Ash Deposition on Photosynthesis, Growth and Yield of Rice. Bull Environ Contam Toxicol 93:106112. https://doi.org/10.1007/s00128-014-1282-x

56. Rashid MS (2003) A study of land transformation in Savar Upazila, Bangladesh, 1915-2001: an integrated approach using remote sensing, census, map and field data. Durham theses, Durham University. Available at: http://etheses.dur.ac.uk/1064/

57. Turekian KK, Wedepohl KH (1961) Distribution of the elements in some major units of the earth's crust. Bull Geol Soc Am 72:175-192. https://doi.org/10.1130/0016-7606(1961)72[175:DOTEIS]2.0.CO;2

58. USEPA, Method 3051A (2007) Microwave Assisted Acid Dissolution of Sediments, Sludges, Soils, and Oils, Revision 1. United States Environmental Protection Agency, Washington, DC

59. USEPA (1996) U.S. Environmental Protection Agency, Soil Screening Guidance: Technical Background Document. EPA/540/R-95/128. Office of Solid Waste and Emergency Response

60. USEPA (2011a) Integrated Risk Information System (IRIS). U.S. Environmental Protection Agency 
61. USEPA (1989) Risk assessment guidance for Superfund. Volume I: human health evaluation manual (Part A), Interim Final. US Environmental Protection Agency, Office of Emergency and Remedial Response, (EPA/540/1-89/002)

62. USEPA (2004) Risk Assessment Guidance for Superfund Volume I: HumanHealth Evaluation Manual (Part E, Supplemental Guidance for Dermal Risk Assessment). US Environmental ProtectionAgency, Washington, DC

63. USEPA (2011b) Risk assessment guidance for Superfund: volume III part A, process for conducting probabilistic risk assessment. US Environmental Protection Agency, Washington, DC

64. Wang J, Chen Z, Sun X et al (2009) Quantitative spatial characteristics and environmental risk of toxic heavy metals in urban dusts of Shanghai, China. Environ Earth Sci 59:645-654. https://doi.org/10.1007/s12665-009-0061-1

65. Wang Q, Lu X, Pan H (2016) Analysis of heavy metals in the re-suspended road dusts from different functional areas in Xi'an, China. Environ Sci Pollut Res 23:19838-19846. https://doi.org/10.1007/s11356-016-7200-5

66. Wang X, Liu E, Lin Q et al (2020) Occurrence, sources and health risks of toxic metal(loid)s in road dust from a mega city (Nanjing) in China. Environ Pollut 263:114518. https://doi.org/10.1016/j.envpol.2020.114518

67. Wiesner MR, Lowry GV, Jones KL et al (2009) Decreasing Uncertainties in Assessing Environmental Exposure, Risk, and Ecological Implications of Nanomaterials † ‡. Environ Sci Technol 43:6458-6462. https://doi.org/10.1021/es803621k

68. Xiao Q, Zong Y, Malik Z, Lu S (2020) Source identification and risk assessment of heavy metals in road dust of steel industrial city (Anshan), Liaoning, Northeast China. Hum Ecol Risk Assess 26:1359-1378. https://doi.org/10.1080/10807039.2019.1578946

69. Xu C, Zhang Q, Gao L et al (2019) Spatial distributions and transport implications of short- and medium-chain chlorinated paraffins in soils and sediments from an e-waste dismantling area in China. Sci Total Environ 649:821-828. https://doi.org/10.1016/j.scitotenv.2018.08.355

70. Yang Z, Lu W, Long Y et al (2011) Assessment of heavy metals contamination in urban topsoil from Changchun City, China. J Geochemical Explor 108:27-38. https://doi.org/10.1016/j.gexplo.2010.09.006

71. Yesilkanat CM, Kobya Y (2021) Spatial characteristics of ecological and health risks of toxic heavy metal pollution from road dust in the Black Sea coast of Turkey. Geoderma Reg 25:e00388. https://doi.org/10.1016/j.geodrs.2021.e00388

72. Yu W, Liu R, Wang J et al (2015) Source apportionment of PAHs in surface sediments using positive matrix factorization combined with GIS for the estuarine area of the Yangtze River, China. Chemosphere 134:263-271. https://doi.org/10.1016/j.chemosphere.2015.04.049

73. Zhang J, Hua P, Krebs P (2017) Influences of land use and antecedent dry-weather period on pollution level and ecological risk of heavy metals in roaddeposited sediment. Environ Pollut 228:158-168. https://doi.org/10.1016/j.envpol.2017.05.029

74. Zhao W, Ding L, Gu X et al (2015) Levels and ecological risk assessment of metals in soils from a typical e-waste recycling region in southeast China. Ecotoxicology 24:1947-1960. https://doi.org/10.1007/s10646-015-1532-7

75. Zhu X, Yu W, Li F et al (2021) Spatio-temporal distribution and source identification of heavy metals in particle size fractions of road dust from a typical industrial district. Sci Total Environ 780:146357. https://doi.org/10.1016/j.scitotenv.2021.146357

\section{Figures}




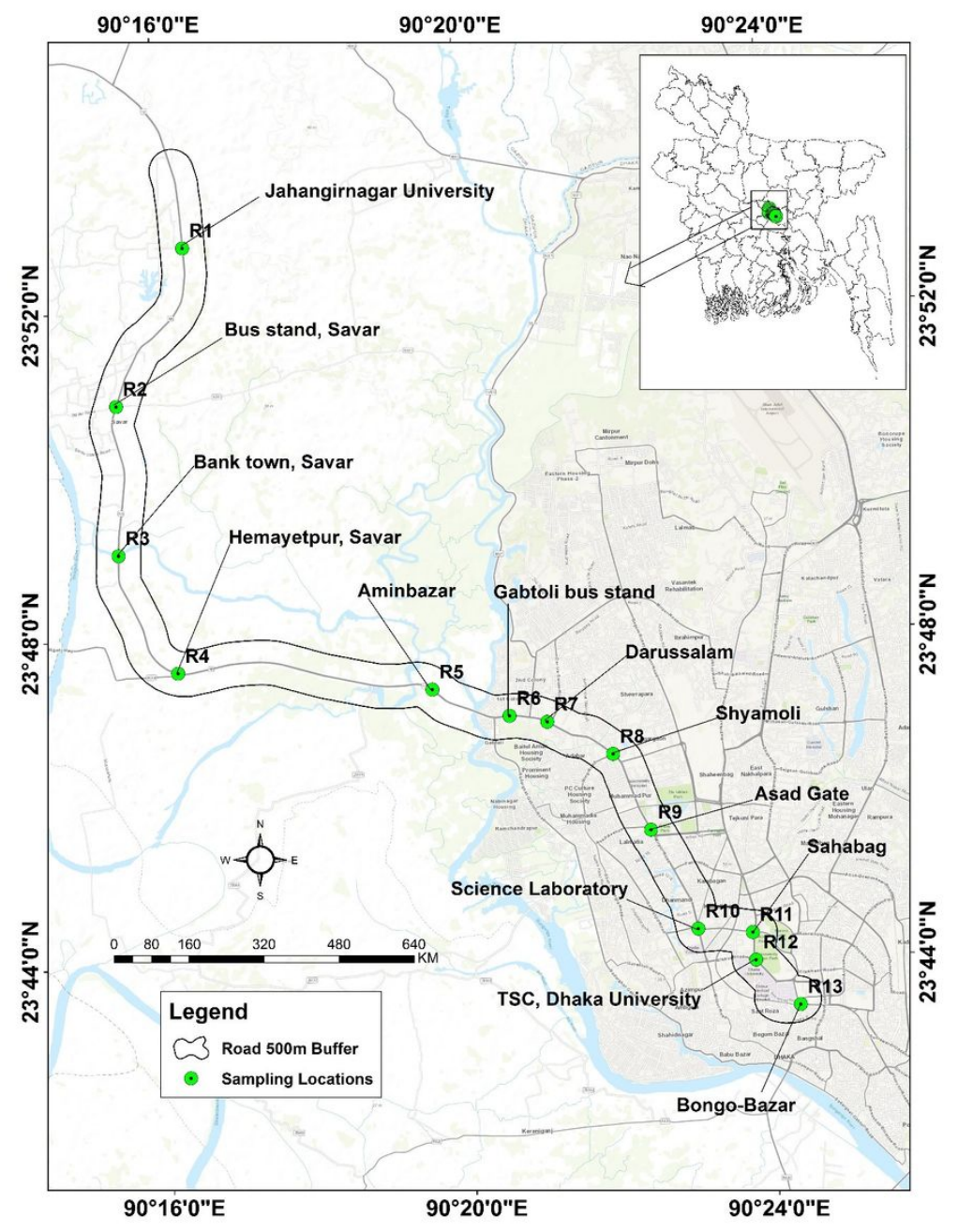

Figure 1

Map of the study area with the sampling locations (the studied road buffered $500 \mathrm{~m}$ for spatial distribution). 

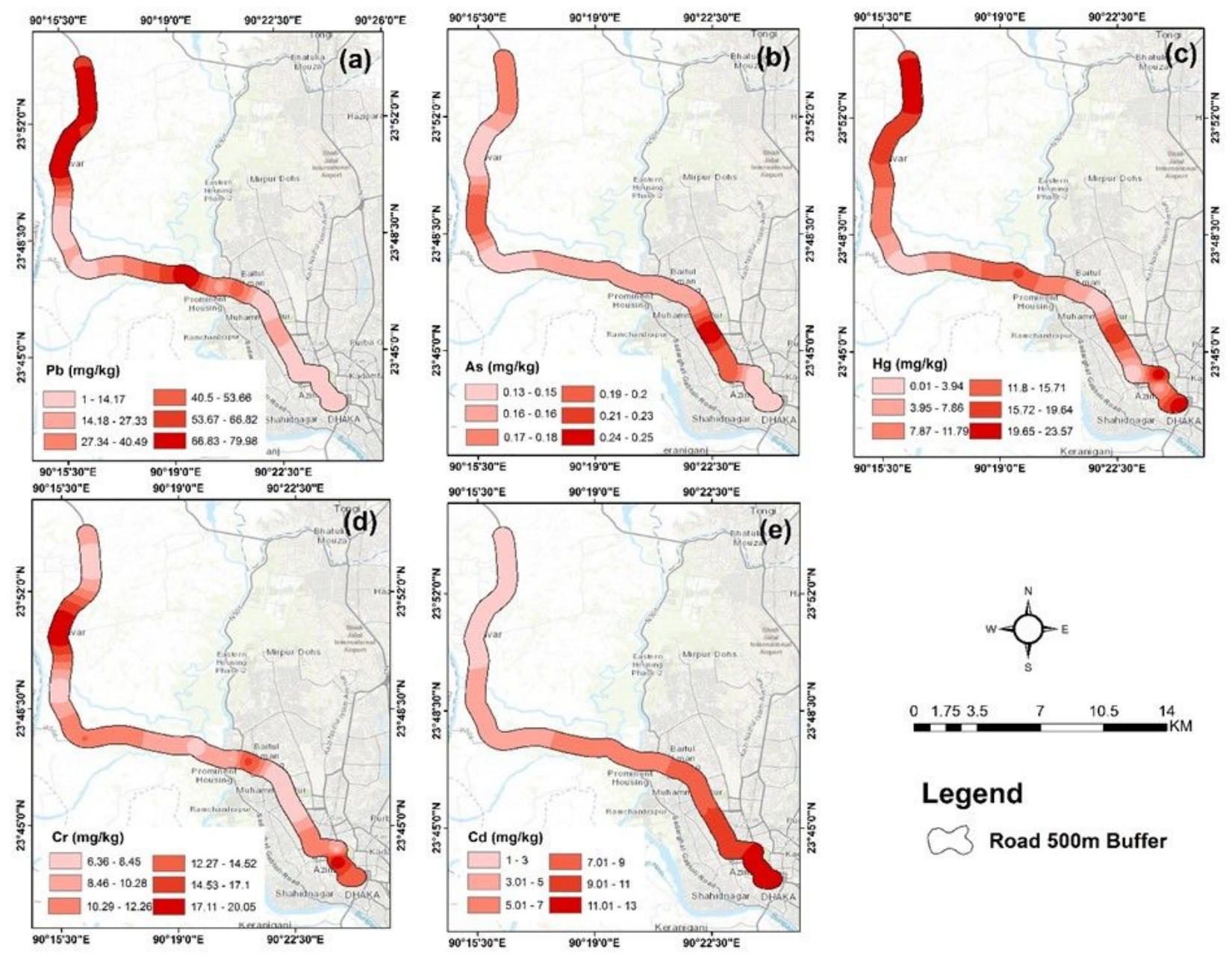

\section{Legend}

Road 500m Buffer

Figure 2

Spatial distribution of toxic metals concentration for (a) Pb, (b) As, (c) Hg, (d) Cr and (e) Cd in road dust sample of Dhaka City and Dhaka-Aricha Highway, Bangladesh.
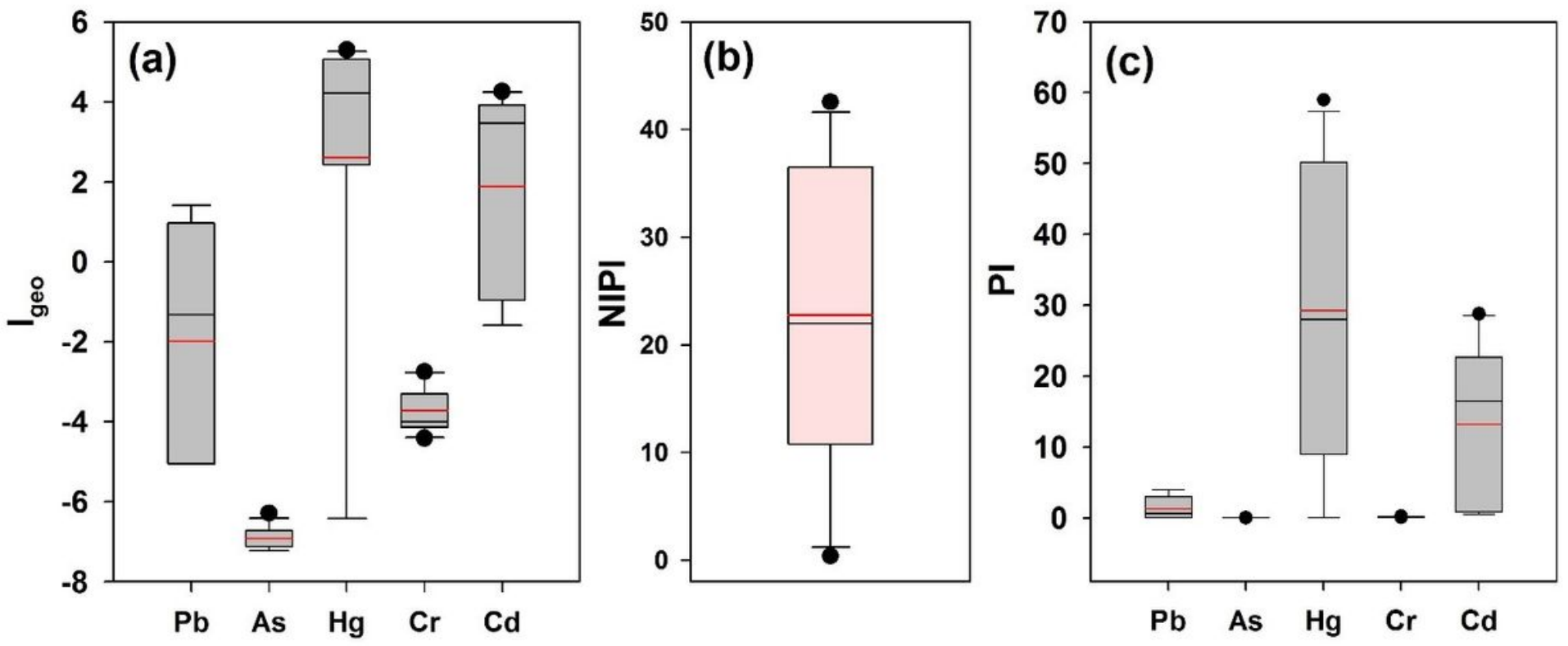

Figure 3

Results of metals pollution assessment from road dust associated toxic metals exposure in Dhaka City and Dhaka-Aricha Highway. Sub-figures (a) shows contribution of toxic metals in geo-accumulation index (Igeo); (b) resulted nemerow integrated pollution index (NIPI) of toxic metals; (c) contribution of toxic 
metals in single-factor pollution index (PI). The horizontal black and red lines of the box plots are the median and mean value, respectively. Each box covers the 25 th to 75 th percentile, whereas the whiskers represent the 10 th and 90 th percentile.
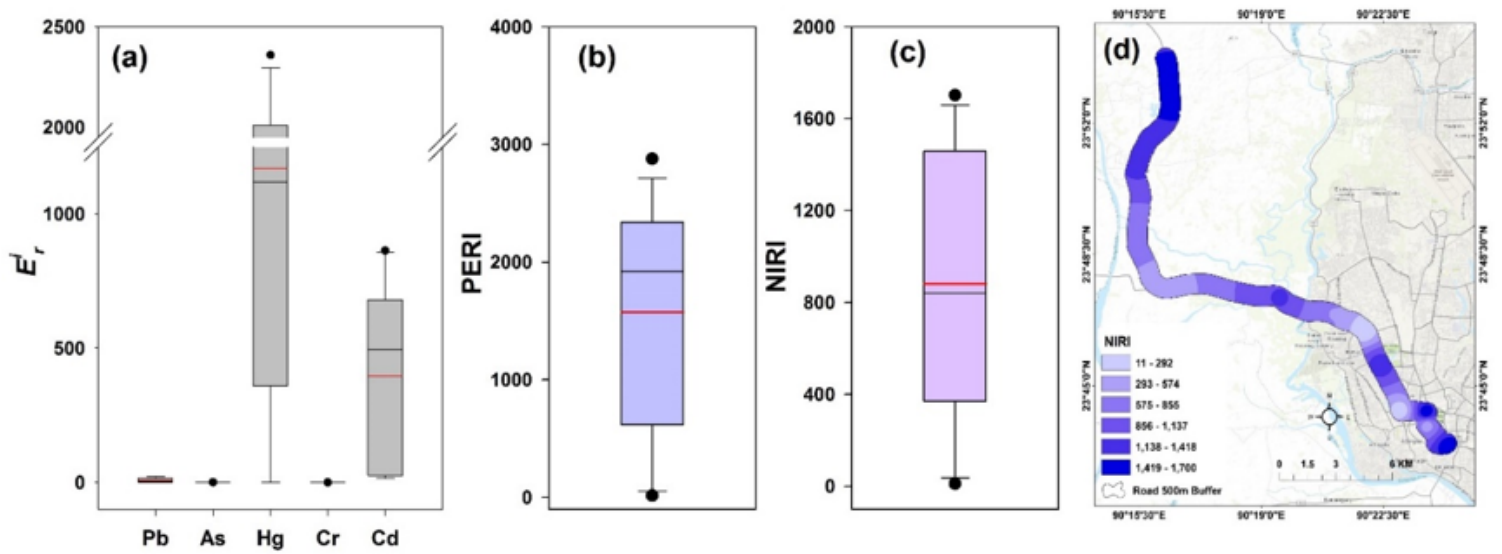

Fig. 4. Results of ecological risk assessment of toxic metals, (a) shows contribution of toxic metals in potential ecological risk $\left(\mathrm{E}_{\mathrm{r}}^{\mathrm{i}}\right)$; (b) potential ecological risk index (PERI) values from toxic metals; (c) nemerow integrated risk index (NIRI) values of study area and (d) risk distribution. The horizontal black and red lines of the box plots are the median and mean value, respectively. Each box covers the 25 th to 75 th percentile, whereas the whiskers represent the 10th and 90th percentile.

\section{Figure 4}

See image above for figure legend 


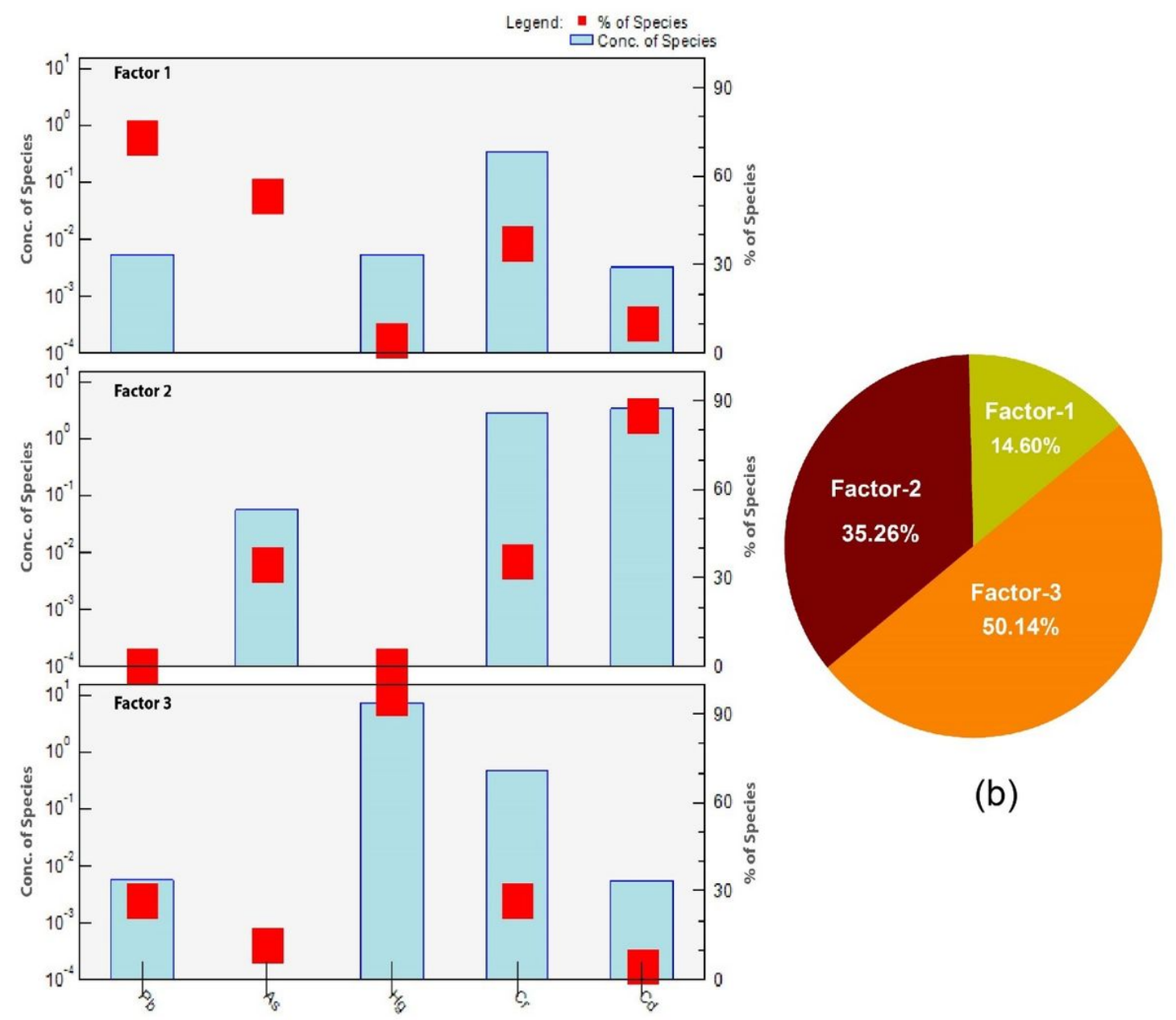

(a)

\section{Figure 5}

Positive matrix factorization (PMF) results; (a) contributions of factors to each toxic metal and (b) total contributions of factors to the toxic metals in road dust.

\section{Supplementary Files}

This is a list of supplementary files associated with this preprint. Click to download.

- HighlightsandGraphicalAbstact.docx

- SupplementaryInformation.docx 